\title{
DATING A PRE-IMPERIAL TEXT: THE CASE STUDY OF THE BOOK OF LORD SHANG
}

\author{
Yuri Pines*
}

\begin{abstract}
This article explores the dating of the Book of Lord Shang (Shangjunshu 商君書). Despite the importance of this text as one of major ideological products of the Warring States period (453-221 в.C.E.), it remained largely ignored in mainstream Western Sinology, in part because of the confusion about the dates of its composition. The article analyzes different criteria employed by earlier scholars to ascertain the dates of individual chapters of the Book of Lord Shang and investigates the relative weight of each of these criteria. This results in a methodologically transparent discussion, which not only advances our understanding of the complex textual history of the Book of Lord Shang but also makes a step toward establishment of a commonly acceptable set of dating determinants which may be employed in investigating the dates of other pre-imperial (i.e. pre-221 B.C.E.) texts.
\end{abstract}

Few issues in studies of early China arouse so much controversy as the question of the dating of major pre-imperial (i.e. pre-221 B.C.E.) texts. Already during the imperial era, particularly during the Song 宋 (9601279) and Qing 清 (1636/1644-1912) dynasties, scholars noticed that many texts traditionally attributed to specific thinkers contain clear anachronisms and may have been written generations after the death of their putative author. Back then, their ideas were bitterly contested by other scholars. ${ }^{1}$ These debates could become politically sensitive, as happened in the final years of the Qing dynasty, when a reformer Kang

* Yuri Pines 尤銳: Beijing Normal University, School of History and Hebrew University of Jerusalem, yuri.pines@mail.huji.ac.il.

This research was supported by the Israel Science Foundation (grant No. 240/15) and by the Michael William Lipson Chair in Chinese Studies. I am deeply indebted to Carine Defoort, Paul R. Goldin, Martin Kern, and Early China reviewers for their insightful comments on early versions of this article. Needless to say, all possible mistakes and misinterpretations are my sole responsibility.

1. For a sample of controversies, see Zhang Xincheng 張新溦, Weishu tongkao 偽書 通考 (Changsha: Shangwu, 1939); Gu Jiegang 顧頴剛, ed. Guji kaobian congkan 古籍考辨 叢刊, Vol. 1 (1955; rpt. Beijing: Shehui kexue wenxian, 2010); Zheng Liangshu 鄭良樹， Xu weishu tongkao 續偽書通考 (Taibei: Xuesheng, 1984).

(C) The Society for the Study of Early China and Cambridge University Press 2016 
Youwei 康有爲 (1858-1927) based his radically revisionist view of Confucianism on-highly dubious-claims that some of the canonical texts were forged by the associates of the notorious usurper Wang Mang 王莽 (45 B.C.E.-23 C.E.). ${ }^{2}$ In the early Republican era (1911-1949) an assault on traditional dating of major texts was part and parcel of intellectual and cultural awakening and of the break with traditional culture in general, and this was the case for a number of Japanese scholars as well. ${ }^{3}$ A further upsurge in the debate surrounding the dates of pre-imperial texts occurred in China in the 1980s, and publications on the topic continue, albeit with lesser frequency, well into the present day. ${ }^{4}$ Yet despite an impressive harvest of scholarly manuscripts and articles, few if any controversies have been settled. It is fair to conclude that on this topic the scholarly community in China, Japan, and the West agrees primarily to disagree.

Even a cursory survey of current treatment of the texts attributed to pre-imperial Masters (or Philosophers, $z i$ 子) will show a huge variety of approaches. While many scholars (especially those coming from the field of philosophy) habitually treat these texts as if they were really penned by the putative author, others insist that the Masters are creations of the texts no less than the texts are creations by the Masters. ${ }^{5}$ Some believe that even a lengthy text-such as, e.g., the Zuo zhuan 左 傳一can be dated with great precision, while others argue that even short texts like the Laozi 老子 are "composite" in their nature: they

2. See Kang Youwei, Xinxue wei jing kao 新學偽經考 (1891, rpt. Beijing: Guji, 1956); for pointing out the weaknesses of Kang's analysis, see, e.g., Hans van Ess, "The Old Text/New Text Controversy: Has the 2oth Century Got It Wrong?" T'oung Pao 80.13 (1994), 146-70.

3. In China, an iconoclastic assault on the past, especially on traditional dating, is usually associated with Gu Jiegang 顧頴剛 (1893-1980) and his associates. In Japan, one of its most radical representatives was Tsuda Sōkichi 津田左右吉 (1873-1961); see Tsuda, Saden no shisō shiteki kenkyū 左傳の 思想史的研究 (Tokyo: Iwanami, 1935， rpt. 1958) and Tsuda, Rongo to Kōshi no shiso 論語と孔子の思想 (Tokyo: Iwanami, 1946); for Tsuda's pejorative views of China's culture, see Joël Joos, "A Stinking Tradition. Tsuda Sōkichi's views of China," East Asian History 28 (2004), 1-26.

4. It is impossible to summarize here the great variety of recent Chinese studies on the topic of the texts' dating; for a single recent example, see Li Rui 李銳, “Xian Qin gushu niandai wenti chu lun-yi Shangshu, Mozi wei zhongxin” 先秦古書年代問題初 論——《尚書》《墨子》為中心, Xueshu yuekan 學術月刊 2015.3, 141-54; q.v. for further references.

5. For the latter view, see Mark E. Lewis, Writing and Authority in Early China (Albany: State University of New York Press, 1999), 58; Carine Defoort and Nicholas Standaert, "Introduction: Different Voices in the Mozi: Studies of an Evolving Text," in The Mozi as an Evolving Text: Different Voices in Early Chinese Thought, ed. Carine Defoort and Nicholas Standaert (Leiden: Brill, 2013), 8. The former is too ubiquitous to name its proponents. 
could be repeatedly rearranged and reassembled from smaller textual units, which makes the very notion of "dating" highly tenuous. ${ }^{6}$ Nor is there an agreement on which factors should be given priority in determining the text's date. Should we focus primarily on the text's internal information (e.g. references to historical events and personages), on its vocabulary and grammar, on its relations with other texts, on references to it in later (e.g. Han 漢 [206/202 B.C.E.-220 C.E.]) literature, or on anything else?

In a recent insightful study Paul Fischer outlined the evolution of authentication debates from the Han dynasty to the present day. Fischer analyzed different criteria used in these debates, pointed out their weaknesses, and put forward what appears to be an increasingly popular "polymorphous texts" paradigm. Fischer considers the Masters' texts as "fluid entities variously constructed from related but disparate pericopes circulating independently or in diverse editions." This understanding in his eyes undermines the very reasonability of authentication debates. Fischer concludes: "This paradigm does not, of course, abrogate the field of Authentication studies at one stroke. But it is the greatest challenge to the field in all the years since its inception." ${ }^{7}$

At first glance, Fischer's conclusion undermines not just broadly defined authentication studies but their sub-field, i.e. clarifying the texts' dates. Indeed, if every text and every textual unit was repeatedly reworked and redacted, dating it with any precision becomes pointless. ${ }^{8}$ Yet I believe that this conclusion is premature and also grossly counterproductive. Their fluid nature aside, the Masters' texts and different units thereof-be they clusters of chapters (the forerunners of future books), individual chapters, or just smaller segments (zhang 章)— display clear temporal differences in terms of their content and language, as I hope to demonstrate below. Eschewing the question of the date of their composition severely diminishes our ability to contextualize these texts and to properly position them within pre-imperial and

6. For the first approach, see, e.g., Yang Bojun's dating of the Zuo zhuan-the single largest pre-imperial text-to a short period "between 403 and 389 в.C.E." (Yang Bojun 楊伯峻, “Qianyan” 前言, in Chunqiu Zuozhuan zhu 春秋左傳注 [Beijing: Zhonghua, 1981], 43). For the second, see William G. Boltz, "The Composite Nature of Early Chinese Texts," in Text and Ritual in Early China, ed. Martin Kern (Seattle: University of Washington Press, 2005), 50-78.

7. Paul Fischer, "Authentication Studies (辨偽學) Methodology and the Polymorphous Text Paradigm," Early China 32 (2009), 3 and 40.

8. This is apparently Fischer's personal conclusion. Hence, in his recent study of the Shizi 尸子 (Shizi: China's First Syncretist [New York: Columbia University Press, 2012]) Fischer discusses in detail its textual history but avoids altogether discussion of the possible date of its composition. 
early imperial ideological controversies. Rather than giving up studies of the text's dates, we should incorporate new understandings outlined by Fischer and like-minded scholars and put forward a more cautious, more up-to-date, and more methodologically transparent way of tackling this question.

It is against this backdrop that in what follows I want to address anew problems involved in ascertaining the dates of composition of the Masters' texts. For my case study I have chosen the Book of Lord Shang attributed to Shang Yang 商鞅 (d. 338 B.C.E.), a text to which I have been attracted for some time due to its peculiar social and political stance. The choice is not accidental. Debates about the composition of the Book of Lord Shang and the dates of its component chapters have continued in China and Japan for almost a century; yet in Western scholarship such issues remain largely ignored. ${ }^{9}$ The resultant lack of clarity about the date of the book's composition is one of the reasons for a regrettable neglect of its content in Western Sinology, which I aim to reverse. Besides, I hope that by presenting a methodologically transparent analysis of the text's dating I shall be contributing toward renewed interest in the question of the dating of other Masters' texts. In addition, resolving some of the controversies around the Book of Lord Shang's dates may be helpful to contextualize it within Qin 秦 history and contribute therewith to studies of Qin history in general.

\section{Background: Textual History of the Book of Lord Shang}

The Book of Lord Shang is commonly associated with Shang Yang (aka Gongsun Yang 公孫鞅 or Lord of Shang 商君), ${ }^{10}$ the singularly famous Qin statesman, whose reforms propelled this state to eventual supremacy over the rival polities of the Warring States (Zhanguo 戰 國, 453-221 B.C.E.) era. The thinker and the text associated with him have become hugely controversial ever since the Warring States period; in the eyes of many imperial literati they epitomized political

9. See the survey of Chinese and Japanese scholarship below in the text. In Western languages the singularly systematic discussion of the text's dating by Jan J. L. Duyvendak (The Book of Lord Shang: A Classic of the Chinese School of Law [London: Probsthain, 1928; rpt. Chicago: University of Chicago Press, 1963], 141-59) was a major achievement of its time, but by now it has become quite outdated. The same can be said of Leonard S. Perelomov's discussion (Kniga Pravitelia Oblasti Shan (Shangjunshu) [Moscow: Nauka, 1968; rpt. Moscow: Ladomir 1993], 21-38).

10. Shang 商 is a fief granted to Gongsun Yang in 34 O B.C.E., just two years before his downfall and execution. The precise translation of Shangjunshu 商君書 should be Book of Shang's Lord or Book of the Lord of Shang, but since the Book of Lord Shang has become ubiquitous in English studies, I prefer to retain it. 
amorality—or, worse, immorality—and did not merit scholarly attention. This trend of "being ashamed to speak about Shang Yang,"11 reflects the attitudes of not just many traditional scholars but also many modern ones, particularly in the West. ${ }^{12}$

The first references to writings associated with Shang Yang come from an ideologically close text, the Han Feizi 韓非子. On one occasion, when urging the ruler to be ready to alter existing norms and regulations and to dispense, when necessary, with public opinion, Han Fei 韓非 (d. 233 B.C.E.) says: “it is explained in the 'Internal and External' of Lord Shang" (shuo zai Shangjun zhi 'nei wai') 說在商君之〈內外〉. ${ }^{13}$ The current Book of Lord Shang does not include a chapter "Internal and External" (nei wai 内外); judging from the content of Han Fei's argument, he refers to what is currently the first chapter of the Book of Lord Shang, "Revising the laws" ("Geng fa" 更法). Elsewhere, Han Fei cites Shang Yang directly. After explicating Shang Yang's principle of imposing heavy punishments on minor offenses, Han Fei says:

\section{公孫鞅曰: 行刑, 重其輕者——輕者不至, 重者不來。是謂以刑去刑。}

Gongsun Yang said: "When punishments are implemented, inflict heavy [punishments] on light [offences]: then light [offences] will not come, and heavy [ones] will not arrive. This is called: to eradicate punishments with punishments." 14

This statement by Gongsun Yang (i.e. Shang Yang) appears almost verbatim in two of the chapters of the Book of Lord Shang: 4, "Eliminating the strong" ("Qu qiang" 去強), and 13, "Making orders strict" ("Jin ling" 靳令). ${ }^{15}$ Possibly, then, Han Fei had access to the writings attributed to Shang Yang. Indeed, elsewhere he mentions that

11. A saying by Su Shi 蘇軾 (1036-1101), cited from Dongpo quanji 東坡全集 [e-Siku quanshu edition], 105: 14 .

12. See more in Yuri Pines, "Alienating Rhetoric in the Book of Lord Shang and Its Moderation," Extrême-Orient, Extrême-Occident 34 (2012), 79-80.

13. Han Feizi jijie 韩非子集解, compiled by Wang Xianshen 王先慎 (1859-1922) (Beijing: Zhonghua, 1998), 120 (“Nan mian” 南面, V.18). This chapter of Han Feizi suffers from textual corruption; the original was possibly accompanied by detailed quotations of Shang Yang and of other statesmen mentioned thereafter.

14. Han Feizi, 225 ("Nei chu shuo shang. Qi shu" 内儲說上七術, IX.30).

15. See Shangjunshu 4.4 and 13.5. In referring to the passages of the Book of Lord Shang I indicate the chapter and the paragraph following the divisions that I adopt in my forthcoming translation of the text (Yuri Pines, The Book of Lord Shang: Apologetics of State Power in Early China [New York: Columbia University Press]). In most cases these divisions are identical to those proposed by Zhang Jue 張覺, Shangjunshu jiaoshu 商君書校疏 (Beijing: Zhishi chanquan, 2012), in which case I do not provide a further reference. Whenever my divisions differ from those of Zhang, a specific reference to his edition follows. 
families within the boundaries possess "laws/methods of Shang [Yang] and Guan [Zhong]" (Shang Guan zhi fa 商管之法). ${ }^{16}$ Judging from the context, these "laws" or "methods" ( $f a$ 法) refer not only to legal or administrative regulations bequeathed by these statesmen but to the texts attributed to them, i.e. the [proto-] Book of Lord Shang and [proto-] Guanzi 管子. ${ }^{17}$ If Han Fei is right, then the Book of Lord Shang might have circulated broadly in the Chinese world on the eve of imperial unification.

The Book of Lord Shang was relatively well known throughout the Former Han dynasty 前漢 (206/202 B.C.E.-9 C.E.). Several eminent Han statesmen reportedly studied Shang Yang's teachings, and his ideas were openly endorsed by a few leading courtiers. ${ }^{18}$ Sima Qian 司馬遷 (c. $145-90$ B.C.E.) claims to have read at least two chapters of the Book of Lord Shang, viz. "Opening the barred" ("Kai sai" 開塞) and "Agriculture and warfare" ("Nong zhan" 農戰). The first of these chapters is mentioned also in a slightly earlier treatise, Huainanzi 淮南子 (c. 14 O B.C.E.). ${ }^{19}$ By the end of the Former Han dynasty, the first catalog of the imperial library was compiled by Liu Xiang 劉向 (79-8 B.C.E.) and his associates. The catalog mentions the book named Lord Shang 商君 in twenty-nine chapters in the "Legalists" (fajia 法家) sub-section of the "Masters" (or "Philosophers," zi 子) books. Separately, it lists a book named Gongsun Yang 公孫鞅 in twenty-seven chapters in the "Strategists" (bing quanmou 兵權謀) sub-section of "Military books" (bing shu 兵書). This latter may well be another version of the Book of Lord Shang. ${ }^{20}$

16. Han Feizi, 451 (“Wu du” 五冨, XIX.49).

17. Guanzi is a heterogeneous collection produced between the fourth and the second century B.C.E., attributed to a Qi statesman Guan Zhong 管仲 (d. 645 B.C.E.).

18. Students of Shang Yang's teachings include such eminent personalities as Chao Cuo 昆錯 (d. 154 B.C.E.) and Dongfang Shuo 東方朔 (fl. 130s B.C.E.) (Hanshu 49: 2276; 65: 2864). The influence of The Book of Lord Shang on Chao Cuo is particularly observable from Chao's memorials (Christian Schwermann, "From Theory to Practice? Putting Chao Cuo's Memorials on Economics and Finance into Historical Perspective," in Between Command and Market: Economic Thought and Practice in Early China, ed. Christian Schwermann and Elisa Sabattini [Leiden: Brill, forthcoming]). Shang Yang and his legacy were openly endorsed by the government side during the Salt and Iron Debates in 81 B.C.E. (see, e.g., Yantie lun jiaozhu 鹽鐵論校注, annotated by Wang Liqi 王利器 [Beijing: Zhonghua, 1996], 93-97 [“Fei Yang” 非鞅, II.7]).

19. See Shi ji 68.2237; The Huainanzi: A Guide to the Theory and Practice of Government in Early China, trans. and ed. John S. Major et al. (New York: Columbia University Press, 2010) 20.833.

20. See Hanshu 30.1735 and 30.1757. Wang Shirun 王時潤 (fl. 1915) explained the double record as a lapse by Liu Xiang: while Liu Xiang was in charge of collating 
The Book of Lord Shang continued to circulate in the aftermath of the Han Dynasty's fall in 220 C.E.; it is recorded (under the name Master Shang 商子 or alternately Book of Lord Shang) in the imperial catalogues of the Sui 隋 (581-618) and Tang 唐 (618-907) dynasties; both mention the text as comprising five scrolls (juan 卷) and do not refer to the number of chapters (pian 篇). ${ }^{21}$ Under the Tang, the Book of Lord Shang was still relatively well known; sections of it were incorporated by Wei Zheng 魏徵 (580-643) in his Essentials of Orderly Rule from Multiple Books (Qunshu zhiyao 群書治要, compiled in 631), and references to it appear in the Comprehensive Institutions (Tong dian 通典) by Du You 杜佑 (735-812). ${ }^{22}$ However, by the time of the Song Dynasty 宋 (9601279) we have first indications of textual corruption in the Book of Lord Shang. Zheng Qiao 鄭樵 (1104-1162) mentions in the bibliographic section of his Comprehensive Treatises (Tong zhi 通志) that three of the twenty-nine chapters mentioned in the Han catalog are lost; a similar statement is made in the Bibliographic Treatise from the Jun Studio (Jun zhai dushu zhi 郡齋讀書志) by Chao Gongwu 星公武 (1105-1180). ${ }^{23}$ By the end of the Song dynasty, one more chapter is reported to have been lost, and by the end of the Yuan dynasty 元 (1271-1368) another had followed. ${ }^{24}$ In the early Ming Dynasty 明 (1368-1644) two versions of the text existed, one with twenty-five and another with twenty-four chapters, but it was only the latter, shorter, one that continued in circulation. ${ }^{25}$ Currently available recensions all miss chapters 16 and 21 of the

and recording the Masters' texts in the Han imperial catalog, the military texts were collated independently by Ren Hong 任宏 (fl. 30-10 в.С.E.). The final catalog, Bielu 別 錄, and its subsequent abridgment, Qilue 七略, prepared by Liu Xiang's son, Liu Xin 劉歆 (46 B.C.E.-23 C.E.), contained quite a few double records of the texts collated by both scholars. Most of these double records were erased by the historian Ban Gu 班 固 (32-92 C.E.) who incorporated Qilue in the bibliographical treatise of his History of the Former Han Dynasty (Hanshu 漢書 30.1757). Among the books eliminated by Ban $\mathrm{Gu}$ from the military section, one finds texts associated with Guanzi 管子, Xunzi 荀子 (named Sun Qingzi 孫卿子), He Guanzi 鶡冠子 and the like, all of whom are listed separately in the "Masters" section. Wang Shirun's analysis is cited in Zhang Jue, Shangjunshu, 331 .

21. See Suishu 34.1003; Jiu Tangshu 47.2031.

22. See, for instance, Tong dian 1.7 (e-Siku quanshu edition), which refers to chapter 15 of the Book of Lord Shang.

23. Tong zhi 68.1 (e-Siku quanshu edition); Jun zhai dushu zhi 30.20-21 (e-Siku quanshu edition).

24. For the twenty-five-chapter version, see comment by Chen Zhensun 陳振孫 (c. 1183-1262) in his Zhizhai shulu jieti 直齋書錄解題 10.1 (e-Siku quanshu edition); the twenty-four-chapter Yuan recension (lacking chapters 16 and 21) was the one utilized by Yan Wanli 嚴萬里 (1762-1843) for his collation (see below in the text).

25. The twenty-five-chapter recension was in the possession of Song Lian 宋濂 (1310-1381), as recorded in his Wenxian ji 文憲集 27.66 (e-Siku quanshu edition). 
twenty-six-chapter Song version. Of the three chapters that had been lost between the Han and the Song dynasties, only one fragment survived in Wei Zheng's compilation. ${ }^{26}$

The loss of chapters is only the most visible aspect of the text's deterioration over the centuries. To this, one should add many instances of textual corruption within the surviving chapters. This corruption is most obvious in the chapters that deal with military matters (especially chapters 10-11, of which only fragments remained intact) and specific administrative and military regulations, such as chapter 19. It seems that early scribes and later literati who were in charge of reproducing the text were less acquainted with matters peculiar to the book's immediate military and administrative context, which resulted in several lacunae, misplaced slips, miswritten characters or later typos, and the like.

Aside from direct corruption, the Book of Lord Shang suffered from centuries of neglect by the imperial literati, which resulted in minimal editorial efforts on their part. The book was never divided into paragraphs and sentences (zhangju 章句); it had almost no annotations (only a few glosses by anonymous commentators are found in a single early recension); ${ }^{27}$ and we know of no serious scholarly work on it prior to the very end of the eighteenth century. This neglect made the text notoriously difficult for later readers, and may explain why they often eschewed it, preferring to learn about Shang Yang's legacy from a much better preserved "Biography of Lord Shang" ("Shangjun liezhuan" 商君列傳) in Sima Qian's Records of the Historian (Shi ji 史記). This tendency regrettably persists well into the present day, although it is clear that Sima Qian's account is not accurate and should be read cum grano salis insofar as Shang Yang's career and ideas are concerned. ${ }^{28}$

Nowadays, the earliest surviving recensions of the Book of Lord Shang come from the sixteenth and early seventeenth centuries, i.e. the latter

26. The titles of chapters 16 and 21 are preserved in most recensions: these are "Essentials of punishments" ("Xing yue" 刑約) and "Protecting from robbers" ("Yu dao" 禦盜). The fragment preserved by Wei Zheng belongs to a chapter "Six laws" (“Liu fa" 六法), which, judging from its placement in Wei Zheng's collection, was among the first chapters in the Tang dynasty version of the Book of Lord Shang.

27. The old glosses of an unidentified author survive in an edition prepared by Feng Jin 馮覲 in 1559 which exists now only in a 1626 recension prepared by Feng's grandson Feng Zhi 馮䞇 (for details, see Zhang Jue, Shangjunshu, 307-8).

28. For problems concerning Shang Yang's biography in the Shi ji, to give a single example will suffice: Sima Qian defines Shang Yang as a follower of the school of "forms and names" (xing ming 刑名) (Shi ji 68.2227); yet these two terms never appear together in the Book of Lord Shang! See more criticism of this biography in Yoshimoto Michimasa 吉本道雅, “Shō Kun henhō kenkyū josetsu” 商君變法研究序 說, Shirin 史林 83-84 (2000), 1-29. 
half of the Ming dynasty. ${ }^{29}$ Yet all these are superseded by the first known critical edition of the text prepared by the great Qing man of letters, Yan Wanli 嚴萬里, better known by his later name, Yan Kejun 嚴可均 (1762-1843). ${ }^{30}$ Yan had in his possession a recension of the Book of Lord Shang dating back to the Yuan dynasty; he collated it with two Ming recensions and published a new text in 1793. Later, Yan (now under the name of Yan Kejun) prepared a second improved edition (1811), but it was the first one which became more popular, being republished in 1876 by Zhejiang Publishing House as part of the compilation Twenty-two Masters (Ershier zi 二十二子). This later version-which corrected some of Yan's typographical errors but unfortunately made a few new ones-became the foundation for most subsequent publications of the Book of Lord Shang throughout the twentieth century. ${ }^{31}$

The publication of Yan Wanli's critical edition, as well as renewed interest in Shang Yang and his legacy from the second half of the nineteeth century, for the first time prompted Qing literati to engage in collating and glossing the Book of Lord Shang. By the late nineteenth century, the book had benefited from efforts of such eminent scholars as Sun Xingyan 孫星衍 (1753-1818), Yu Yue 俞栰 (1821-1907), and Sun Yirang 孫詒讓 (1848-1908). ${ }^{32}$ Their efforts in turn influenced many new annotated editions published through the Republican Period (1912-1949). Of these the most notable are those by Wang Shirun (1915), which served as the basic text for Duyvendak's English translation; Zhu Shizhe 朱師轍 (1921, revised in 1948 [republished in 1956]),

29. The discussion of various currently available recensions is based on Zhang Jue, Shangjunshu, 305-51.

30. Yan Kejun's most famous project was a compilation of the surviving texts from the pre-Tang period, resulting in his magnum opus Complete Texts of High Antiquity, Qin, Han, the Three Kingdoms, and the Six Dynasties (Quan shanggu Sandai Qin-Han Sanguo Liuchao wen 全上古三代秦漢三國六朝文). For the identity of Yan Wanli as Yan Kejun, see Cao Hongjun 曹紅軍, “YYan Kejun' 'Yan Wanli' bian” “嚴可均”、“嚴 萬里” 辨, Wenjiao ziliao 文教資料 1996.6, 105-8; Tong Weimin 全衛敏, Chutu wenxian yu Shang jun shu zonghe yanjiu 出土文獻與《商君書》綜合研究 (Vols. 16-17 of Gudian wenxian yanjiu jikan 古典文獻研究輯刊, ed. Pan Meiyue 潘美月 and Du Jiexiang 杜潔祥; Taibei: Hua Mulan, 2013), 7-8n27.

31. For the list of typos in Yan's recension, and in that of Zhejiang publishers, see Zhang Jue, Shangjunshu, 321-23.

32. It is interesting to notice parallels between the revival of interest in the Book of Lord Shang and in the Mozi 墨子. However, it seems that the impact of the late Qing literati on shaping attitudes toward Mozi (for which see Carine Defoort, "The Modern Formation of Early Mohism: Sun Yirang's Exposing and Correcting the Mozi," Toung Pao 101.1-3 [2015], 208-38) was much greater than their impact on subsequent studies of the Book of Lord Shang. 
which served as the basic text for Perelomov's Russian translation); and that of Jiang Lihong 將禮鴻 (1944, published in 1996), which eventually became the standard version in the Mainland, being incorporated into the New Edition of the Masters Collection (Xinbian zhuzi jicheng 新編諸子 集成).

After the establishment of the People's Republic of China (1949), textual work on the Book of Lord Shang slowed, but all of a sudden accelerated in the early 1970 in the context of the anti-Confucian campaign, when Shang Yang was lionized as a "progressive" thinker whose legacy deserved the utmost attention. ${ }^{33}$ Many publications on Shang Yang and the Book of Lord Shang appeared then, but most have little, if any, scholarly value. One stands apart though, Gao Heng's 高亨 (1900-1986) The Book of Lord Shang, Commented and Translated. ${ }^{34}$ Gao, who studied the Book of Lord Shang long before the Cultural Revolution (1966-1976), managed to avoid blatant politicization and presented balanced and academically solid work, which by far surpassed that of his predecessors. The only significant defect of his publication is the use of simplified characters, which makes his edition less appropriate for a critical study of the text.

In recent decades, many editions of the Book of Lord Shang have been published, but few merit mention; in most cases scholars simply reproduced earlier recensions and Gao Heng's translation into colloquial Chinese (baihua 白話). The major exceptions to this rule are several publications by Zhang Jue 張覺, who became deeply engaged in studying the Book of Lord Shang in the early 1990s. His efforts culminated in a new critical edition (2012), which fully benefited from modern library facilities, and which by far supersedes anything published on the Book of Lord Shang heretofore. ${ }^{35}$ Zhang Jue consulted ten different recensions from the Ming and Qing period and, according to his testimony, "selected the best" of each without exclusively following any of them. His work records all cases of textual discrepancies among various recensions, collects most of the earlier commentaries, and thus is immensely helpful for researchers. Moreover, it contains a rich apparatus of auxiliary materials, including detailed introductions to each of the extant early recensions of the Book of Lord Shang.

33. See, e.g., Beijing Daxue Rufa douzheng shi bianxie xiaozu 北京大學儒法鬥爭史 編寫小組, Rufa douzheng shi gaikuang 儒法鬥爭史概况 (Beijing: Renmin, 1975). See more in Li Yu-ning, ed., Shang Yang's Reforms and State Control in China (White Plains, NY: Sharpe, 1977).

34. Gao Heng 高亨, Shangjunshu zhuyi 商君書注譯 (Beijing: Zhonghua, 1974).

35. Zhang Jue, Shangjunshu. 
Needless to say, my research on the Book of Lord Shang has benefited enormously from Zhang Jue's efforts, and in what comes next I normally follow his edition, unless indicated otherwise. It should be noticed, however, that even this excellent edition suffers from several flaws. Zhang Jue's parsing of the text and his attempts to divide it into paragraphs and sentences are not always convincing. Some of his personal glosses are of lower quality than could have been expected; and his marked lack of interest in recent studies is self-defeating. Zhang neither incorporates insights from excavated materials, nor appears to be interested in these in general. Moreover, his repeated attacks on Gao Heng result in the rejection of many sensible suggestions made by Gao, and sometimes in glossing over Gao's views. These negative aspects notwithstanding, Zhang's work remains an impressive scholarly achievement, to which I am immensely indebted.

\section{Debates over the Text's Dating}

Because of the lackluster interest in the Book of Lord Shang on the part of imperial literati, there were very few discussions of its dating throughout the imperial period. Traditional scholars focused-if they did at all—not on the text's dates but on its authenticity, i.e. whether or not it was composed by Shang Yang. The first known instances of questioning Shang Yang's authorship date from the Southern Song dynasty 南宋 (1127-1279). Zhou Duanchao 周端朝 (1172-1234) observed that the book refers to "a lot of later affairs" (duo fuhui houshi 多附會後事) and contains "redundant and excessive words" (fanlan yinci 汎濫淫辭). ${ }^{36} \mathrm{He}$ concluded that the book was inadequate as an introduction to Shang Yang's ideas; instead, it was better that one read the biography in the Records of the Historian. The poor literary quality of the text was also observed by Huang Zhen 黃震 (1213-1280), who claimed that the book is too "disordered" (fanluan 煩亂) to have been produced by a "gifted law official" such as Shang Yang: "its authenticity is doubtful and cannot be verified" (zhenwei dai wei kezhi 真临殆未可知). ${ }^{37}$ These comments did not inspire further studies of the text. It was only under the Qing dynasty that more substantial claims were made about the book's authenticity. Some scholars, such

36. Cited in Ma Duanlin's 馬端臨 (1254-1332), Wenxian tongkao 文獻通考 212.7 (e-Siku quanshu edition). Zhou is identified in Ma Duanlin's compendium only as "Mr. Zhou"; his identity was tentatively restored by Tong Weimin 全衛敏, “Zhou Shi 'She bi' kao" 周氏〈涉筆〉考, Guji zhengli yanjiu xuekan 古籍整理研究學刊 2007.1, 89-93.

37. Huang Zhen, Huangshi richao 黄氏日抄 55.30 (e-Siku quanshu edition). 
as Ma Su 馬㴋 (1621-1673) and Wang Zhong 汪中 (1745-1794) remarked that chapter 15, "Attracting the People" ("Lai min" 徠民), is obviously late. ${ }^{38}$ The compilers of the great imperial encyclopedic project, the Complete Books in the Four Treasuries (Siku quanshu 四庫全書), opined, in turn, that the entire Book of Lord Shang is late because the first chapter uses the posthumous title of Lord Xiao of Qin 秦孝公 (r. 361338 B.C.E.). If Shang Yang was executed immediately after the lord's death, when could he have prepared this book? ${ }^{39}$ These claims laid the ground for modern scholars doubting the book's authenticity.

During the Republican period, interest in the authenticity of early texts in general, and the Book of Lord Shang in particular, intensified, and the topic was addressed, even if briefly, by almost every eminent scholar of that age. The dominant tendency then was to point out obvious or perceived anachronisms in the text (i.e. references to events that happened after Shang Yang's execution) and dismiss the book in its entirety as a later forgery, unworthy of further study. In the heyday of the atmosphere of "doubting antiquity" (yigu 疑古), a cavalier attitude toward many early texts, including the Book of Lord Shang, prevailed. While a notable minority of scholars were engaged in detailed study of the book, they were clearly outnumbered by those who-echoing Hu Shi 胡適 (1891-1962)-considered Shang Yang an important reformer but not a thinker, and surely not an author of the Book of Lord Shang. ${ }^{40}$

The dismissive attitude toward the Book of Lord Shang displayed in the majority of Republican-period studies reflected several common methodological problems. First, scholars were quite often eager to trumpet

38. See Ma Su's Yi shi 繹史 115.27 (e-Siku quanshu edition); Wang Zhong is cited from Zhang Jue, Shangjunshu, 399.

39. See Ji Yun 紀旳 (1724-1805) et al., Shangzi tiyao 商子提要 (1778) (e-Siku quanshu edition). Shang Yang was reportedly executed by his nemesis, Lord Xiao's heir, King Huiwen of Qin 秦惠文王 (r. 337-311 B.C.E.).

40. For the Republican-period insistence on the lateness of the Book of Lord Shang in its entirety, and its subsequent rejection as a source for Shang Yang's activities and thought see, e.g., Hu Shi 胡適, Zhongguo zhexue shi dagang 中國哲學史大綱 (1919， rpt. Beijing: Dongfang, 1996)，322-23; Liang Qichao 梁啟超, Xian Qin zhengzhi sixiang shi 先秦政治思想史 (1919; rpt. Beijing: Dongfang, 1996), 80; Luo Genze 羅根澤, “Shang jun shu tanyuan" 《商君書》探源 (1935), rpt. in Luo Genze shuo zhuzi 羅根澤 說諸子, compiled by Zhou Xunchu 周勛初 (Shanghai : Shanghai guji, 2001), 369-80; Qian $\mathrm{Mu}$ 錢 穆, Xian Qin zhuzi xi nian 先秦諸子繫年 (1935, rpt. Beijing: Shangwu, 2001), 266-67; Guo Moruo 郭沫若, “Qianqi fajia de pipan” 前期法家的批判 (1945); rpt. in Guo Moruo, Shi pipan shu 十批判書 (Beijing: Zhongguo huaqiao, 2008), 236; Qi Sihe 齊思和, “Shang Yang bianfa kao” 商鞅變法考 (1947), rpt. in Qi Sihe, Zhongguo shi tanyan 中國史探研 (Shijiazhuang: Hebei jiaoyu, 2001), 247-78. In contrast to the somewhat cavalier approach adopted in many of these studies, Duyvendak (Book of Lord Shang, 141-59) made an earnest, even if by now outdated, attempt to distinguish different temporal layers in the Book of Lord Shang. 
the discovery of yet another "anachronism," which, under closer scrutiny, could not be accepted as evidence for the book's lateness. For instance, the fact that chapter 1, "Revising the laws," refers to Lord Xiao of Qin by his posthumous appellation does not necessarily suggest that the chapter was penned after Lord Xiao's death; the ruler's name could have been updated by later editors or transmitters of the text. Similarly, the close similarity between chapter 13 of the Book of Lord Shang and chapter 53, "Chi ling" 飭令, of the Han Feizi does not presuppose, pace Qian Mu 錢穆 (1895-1990), Fu Sinian 傅斯年 (1896-1950), and others that the former is later than the latter; actually, the opposite is much more probable (see below). ${ }^{41}$ But even when there are obvious anachronisms in the Book of Lord Shang (and these are undeniable), does this mean that the entire book is late, or just that a few chapters were composed long after Shang Yang's death? This simple question somehow escaped many of the grand masters of the Republican period, even though the fallacy of their methodology was pointed out quite early, for instance by Chen Qitian 陳啓天 (1893-1984). ${ }^{42}$

The Republican-period legacy of dismissing the Book of Lord Shang remained influential in the West up to the end of the twentieth century, resulting in a minuscule number of studies of the Book of Lord Shang there. ${ }^{43}$ In China and Japan, however, it yielded to a much more sophisticated approach. The dominant scholarly opinion nowadays is that the Book of Lord Shang-like many other pre-imperial texts-came into existence after a long period of accretion, during which chapters or paragraphs were added, altered, and possibly edited out. ${ }^{44}$ With this understanding in mind, scholars are no longer

41. See Qian Mu, Xian Qin zhuzi, 266-67; Fu Sinian 傅斯年, Zhanguo zijia xulun 戰國 子家敍論 (rpt. Shanghai: Shanghai guji, 2012), 58-59. For a detailed analysis of these two chapters' interrelatedness see Zheng Liangshu 鄭良樹, Shang Yang ji qi xuepai 商 鞅及其學派 (Shanghai: Shanghai guji, 1989), 82-103.

42. Chen Qitian 陳啓天, Shang Yang pingzhuan 商鞅評傳 (Shanghai: Shangwu 1935), $113-21$.

43. See, e.g., Angus C. Graham, Disputers of the Tao: Philosophical Argument in Ancient China (La Salle, IL: Open Court, 1989), 267-92, whose views of the Book of Lord Shang (and whose treatment of the text as secondary to Han Feizi in analyzing "Legalist" thought) clearly echo Chinese Republican-period studies. David S. Nivison's lack of interest in Shang Yang's thought may also be related to this trend (Nivison, "The Classical Philosophical Writings," in The Cambridge History of Ancient China, ed. Michael Loewe and Edward L. Shaughnessy [Cambridge: Cambridge University Press, 1999], 745-812). For minuscule interest in the Book of Lord Shang in the West, see Pines, "Alienating Rhetoric," 8o, n. 7 .

44. Among Western scholars, the concept of accretion is discussed briefly by Lewis, Writing and Authority, 58, and Boltz, "The Composite Nature." It was employed most 
engaged in the methodologically untenable attempt to date the entire book as a single entity, but rather try to date its individual chapters and determine their authorship. The roots of this approach are discernible already in the Republican period itself (e.g. works of Chen Qitian and Rong Zhaozu); later it was endorsed by Gao Heng. ${ }^{45}$ Yet it was only with Zheng Liangshu's 鄭良樹 magnum opus (1989) that the concept of accretion can be said to have been fully absorbed into the study of the Book of Lord Shang. ${ }^{46}$

Zheng Liangshu presented an insightful-albeit at times overtly speculative-theory of the formation of the Book of Lord Shang. He reads the Book of Lord Shang as a testimony to the evolution of "Shang Yang's school" (Shang Yang xuepai 商鞅學派). Zheng's highly detailed study outlined what he considers traces of ideological evolution among Shang Yang's followers as reflected in changing emphases in different chapters of the treatise. Zheng's publication was almost immediately followed by another magnum opus by Yoshinami Takashi 好并隆司， who proposed an alternative scenario for the book's formation. ${ }^{47}$ Notably, both scholars asserted that the vast majority of the chapters were produced after Shang Yang's death, although they differed with regard to certain details.

In recent years, attempts to date individual chapters of the Book of Lord Shang and to assert their authorship continue. The current tendency, reflecting the general mood of "trusting antiquity" (xin gu 信古) which is now prominent among Mainland scholars, is to assert that

consistently in E. Bruce Brooks and A. Taeko Brooks, The Original Analects: Sayings of Confucius and His Successors (New York: Columbia University Press, 1998). Alas, the overtly speculative nature of Brooks and Brooks's study (see David Schaberg, "Sell It! Sell It!': Recent Translations of Lunyu," Chinese Literature: Essays, Articles, Reviews [CLEAR] 23 [2001], 115-39) made it difficult to treat the idea of accretion with due seriousness. Fischer ("Authentication," 39-40, n. 107) dismisses the "accretion" paradigm as one that implies "that once a part of the received text has been 'established,' it can only be added to and not removed." I think this statement misrepresents the accretion theory; in fact there is no major contradiction between views of, e.g., Lewis and Boltz and those proposed by Fischer in his "polymorphous text" paradigm. That accretion paradigm can accommodate different textual scenarios is seen from Matthias L. Richter's perceptive distinction between additive and transformative accretion (i.e. one in which new textual segments are added without influencing the original wording, and one that does influence earlier parts of the text). See Richter, The Embodied Text: Establishing Textual Identity in Early Chinese Manuscripts (Leiden: Brill, 2013), 157-70.

45. See Chen Qitian, Shang Yang; Rong Zhaozu 容肇祖, “Shangjunshu kaozheng" 商 君書考證, Yanjing xuebao 燕京學報 21 (1937), 61-118; Gao Heng, Shangjunshu, 6-12.

46. Zheng Liangshu, Shang Yang.

47. Yoshinami Takashi 好并隆司, Shōkunsho kenkyū 商君書研究 (Hiroshima: Keisuisha, 1992). 
most of the chapters were penned by Shang Yang, with only a few added after his death. The most radical representative of this trend is Zhang Jue, ${ }^{48}$ who considers just one single chapter (15, "Attracting the people"), as spurious, and regards all the rest as authentic. Other scholars who recently addressed the dating question are less radical, but in general the dating they propose for most of the chapters is markedly earlier than that put forward by Zheng Liangshu and Yoshinami. ${ }^{49}$

In general, I think that the accretion hypothesis proposed by Zheng Liangshu, Yoshinami Takashi, and other scholars can advance our knowledge of the Book of Lord Shang, were we to avoid certain methodological pitfalls embedded in its simplistic utilization. To begin with, recall that most of the currently extant Warring States-period texts bear the imprint of at least four contributors: the original author, his disciples and followers, later editors, such as Liu Xiang and his associates, and also manifold copyists and transmitters, especially those who, under the Han dynasty, transcribed the pre-Qin texts into a "modern" Han script. The degree of intervention of each of the two latter actors in the text's content is debatable. I accept Sarah Allan's view that the Han copyists' alterations of the Warring States-period texts were "probably not intentional forgeries but editorial changes and misguided attempts to restore an original text or meaning," even though in some cases even a minor change could become ideologically consequential. ${ }^{50}$ As for later editors, their impact could in certain cases be considerable, ranking from a new arrangement of the text, to excision of supposedly "duplicate" or "spurious" chapters and paragraphs, to substitution of barely legible or allegedly "wrong" characters with new ones, tomost annoyingly-adding new textual segments. In a few cases, later editors identify themselves and their rearrangements; ${ }^{51}$ but most of them remain silent, such as in the case of the Book of Lord Shang. This silence does not rule out, however, the possibility of later editors and transmitters' tampering with the text's content.

48. Zhang Jue, Shangjunshu.

49. Zhang Linxiang 張林祥, 'Shang jun shu' de chengshu yu sixiang yanjiu 《商君書》 的成書與思想研究 (Beijing: Renmin, 2008); Tong Weimin, Chutu wenxian.

50. See Sarah Allan, Buried Ideas: Legends of Abdication and Ideal Government in Recently Discovered Early Chinese Bamboo-Slip Manuscripts (Albany, NY: State University of New York Press, 2015), 23-24. For potentially consequential change of just a few characters, see Richter, The Embodied Text, 84-85ff.

51. See, e.g., Sato Masayuki, The Confucian Quest for Order: The Origin and Formation of the Political Thought of Xun Zi (Leiden: Brill, 2003), 30-32 for the case of Xunzi 荀子, or Paul R. Goldin, Confucianism (Durham, NC: Acumen, 2011), 39 for the case of Mengzi 孟子. 
Nor should we treat every chapter a priori as an organic unit to be analyzed in the context of the text's accretion. Actually, chapters differ considerably in their nature. Some were produced as separate essays and circulated independently for a considerable period of time before being put together with other essays to form a "book" such as we have..$^{52}$ These "organic" chapters have a distinct style and are normally well organized, with an identifiable beginning and conclusion; in the case of the Book of Lord Shang many of these might have originated from Shang Yang's and his followers' court memorials (see, e.g., chapters $6,9,15,17,23,24$, and 25). Yet in other cases, a chapter is just a patchwork prepared by later editors from independent paragraphs (zhang 章) associated with a putative author. Chapters 13 and 18 of the Book of Lord Shang may well represent this "composite" type. It makes perfect sense to try to date the organic chapters, but surely not the composite ones.

It is with these understandings in mind that I shall proceed now to present my hypothesis about the dating of some of the book's chapters. I shall try to avoid inevitably speculative attempts to date every single chapter or to guess who its author was. Yet I believe we have enough data to determine with relative precision the dating of at least some of the book's chapters, and to propose tentative dating for many more. At the current stage of our knowledge, any definitive answer regarding the process of the book's accretion is impossible, but even a partial answer will advance us considerably toward a better understanding of the nature and the content of the Book of Lord Shang.

\section{The Text's Dating: A Tentative Reconstruction}

Eighty years ago, Chen Qitian criticized scholars engaged in debates over the dating of the Book of Lord Shang for their lack of methodological rigor. ${ }^{53}$ In the generations that have passed since then, the situation has improved, but a single commonly accepted methodology of assessing the dating of pre-imperial texts and of their component chapters is still not in sight. Creating such a methodology goes beyond the ambitions of the present study; as a preliminary step I shall try carefully to outline different criteria employed and their relative weight in assessing the dates of individual chapters. In particular I shall try to explain why "internal" criteria (e.g. historical information contained in the text, its

52. This may be the reason for which Sima Qian or the Huainanzi authors often cite titles of individual chapters when referring to a Master's oeuvres. For a different explanation, see Martin Kern, "The Masters in the Shiji," T'oung Pao 101.4-5 (2015), 340-42.

53. Chen Qitian, Shang Yang, 113-21. 
language, and, whenever appropriate, interrelations among its chapters) are by far superior to "external" criteria (e.g. references or citations of the text elsewhere). ${ }^{54}$ I hope that the methodological transparency adopted in what follows will encourage further research that will fine-tune my findings.

\section{A. Historical Information}

The first and by far the most convincing criterion for dating a chapter is that of relating its content to what we know of the history of the Warring States period. For instance, it is clear that if a chapter invokes events that occurred after Shang Yang's death, mentions personalities who lived after Shang Yang, or applies terms that were not in existence during his lifetime, it could not have been be authored by him. Yet historical data can not only prove a late date, but also suggest a relatively early one. For instance, since many chapters discuss the ways to unify Allunder-Heaven, but not a single one (with the possible exception of chapter 26, “Fixing divisions" [“Ding fen" 定分]) evinces any knowledge of the eventual imperial unification of 221 B.C.E., it is plausible that most or all of the chapters were composed before the establishment of the Qin Empire. Similarly, insofar as no military chapter refers to cavalry, it is likely that they were produced before the third century B.C.E., by which time cavalry had gained importance in the world of the Warring States, and in Qin in particular. ${ }^{55}$ In such cases, the argumentum ex silentio can be meaningfully employed.

Of all the chapters of the Book of Lord Shang, chapter 15, "Attracting the people," is one of the most easily datable in the entire corpus of pre-imperial texts. Judging from the events it mentions (e.g. the Changping 長平 campaign against the state of Zhao 趙, 262-26o в.C.E.), and from what it does not mention, i.e. Qin's unstoppable expansion from the early 230 в.C.E., it must have been produced in between

54. In his study of "authentication" Fischer conveniently summarizes various criteria used to determine the text's authenticity and also elucidates approaches employed by earlier scholars from the Han to the Republican period. Fischer considers anachronism as "extrinsic" argument, because "a part or the whole of a text is judged anachronistic with regard to other, contemporary writings" (Fischer, "Authentication," 4). I prefer to call the arguments based on the text's content "internal" (Fischer's "intrinsic") rather than "extrinsic."

55. The introduction of cavalry into China proper is commonly associated with reforms of King Wuling of Zhao 趙武靈王 (r. 325-299 B.C.E.) in 307 B.C.E. The story of King Wuling's reforms may be spurious but the usage of cavalry in Chinese armies is indeed unattested before c. 300 B.C.E. In the Book of Lord Shang cavalry is mentioned only in a late chapter, 15 (for which see below in the text). 
these dates. There are other indicators of its dating around 250 в.С.Е., which I shall mention below; but here we can move to other chapters.

Another clearly anachronistic (i.e. post-Shang Yang) chapter is the last one, 26, "Fixing divisions." It depicts an administrative system and employs nomenclature which came into existence only on the eve of the imperial unification. For instance, it mentions the offices of chengxiang 丞相 (prime minister, established in 309 B.C.E.) and yushi 御史 in the meaning of "chief censor" (a meaning acquired on the eve of unification). ${ }^{56}$ In marked distinction to the rest of the book, chapter 26 focuses not on the means to control a single state as a preliminary step before the future unification, but rather on how to rule the entire sub-celestial realm. Since this realm is depicted as comprising both autonomous territories of "regional lords" (zhuhou 諸侯) and centrally ruled commanderies and counties (junxian 郡縣), many scholars have proposed an early Han date for this chapter. Yet this need not be the case: as has been observed by Ōkushi Atsuhiro among others, ${ }^{57}$ on the eve of unification Qin treated some of the neighboring polities ruled by regional lords as its dependencies, which means that the chapter could have been composed back then. In any case, the chapter could not have been produced long before 221 B.C.E., and is probably the latest chapter in the entire Book of Lord Shang.

Two other chapters contain obvious anachronisms. Chapter 9, "Implementing laws" (“Cuo fa" 錯法) mentions a Qin strongman, Wu Huo 烏獲, who was active three decades after Shang Yang's death $\left(\mathrm{Wu}\right.$ Huo was executed in 306 в.С.E.). ${ }^{58}$ The final section of chapter 20, “Weakening the people" ("Ruo min" 弱民), again mentions Wu Huo, and, in addition, refers to a series of events in the state of Chu 楚 that occurred prior to 278 в.C.E. Moreover, inaccuracies in the depiction of the events show that the section under discussion (20.11) was probably composed much later than 278 B.C.E. ${ }^{59}$ Yet, as has been noticed by most

56. Tong Weimin, Chutu wenxian, 219.

57. Ōkushi Atsuhiro 大櫛敦弘, “Shin hō-Unmei Suikochi Shin kan yori mita toitsu zenya” 秦邦一雲夢睡虎地秦簡よち見た「統一前夜」, Ronshū: Chūgoku kodai no moji to bunka 論集: 中國古代の文字と文化 (Tōkyō: Kyūko shoin, 1999), 319-32.

58. For Wu Huo's execution, see Shi ji 5.209. Theoretically it is possible that the section that mentions $\mathrm{Wu}$ Huo does not belong to the original text of the chapter but was added later; yet I found no convincing reasons to support this assertion.

59. The text praises the military strength of the state of Chu 楚, but then adds: "Yet when the Qin army arrived, Yan and Ying were upturned as if they were a withered tree; Tang Mie died at Chuisha, Zhuang Qiao started [rebellion] from within, and Chu was divided into five." Putting aside complexities of Zhuang Qiao's 莊蹻 rebellion, the text clearly mixes two unrelated events. Tang Mie 唐荗 was killed during 
observers, this section was in all likelihood misplaced in chapter 20, because it is not related either topically or stylistically to the rest of the chapter. Putting chapter 20 aside for the time being, we may conclude that at least three chapters $(9,15$, and 26) were obviously composed long after Shang Yang's death.

On several other occasions, historical data allow us to conclude that certain chapters were penned relatively early, i.e. during Shang Yang's lifetime. One of the clearest examples is chapter 2, "Order to cultivate wastelands" ("Ken ling" 墾令). This chapter appears to reflect the situation of an old aristocratic system that was current in the state of Qin prior to Shang Yang's reforms. It remains conspicuously silent about ranks of merit, which were Shang Yang's single most significant innovation; ${ }^{60}$ instead, when it refers to elite members, it cautions against the power of hereditary nobles (dafu 大夫) (2.14), and of the heads of noble lineages (jia zhang 家長) (2.7), i.e. groups that disappeared from Qin's social landscape in the aftermath of Shang Yang's reforms and are never mentioned again in the Book of Lord Shang. Elsewhere, the chapter warns against exemptions from taxation and labor services granted to minor sons of the nobles and to the merchants' servicemen $(2.13,2.18)$, which again hints at the situation in pre-reform Qin society. Besides, some of the chapter's statements, e.g. "when the emoluments are bountiful, taxes are abundant" (2.4), seem likewise to hint at the pre-reform situation, in which the nobles' income derived directly from the subordinate population, whose tax quotas could be adjusted by the master. ${ }^{61}$ If this is the case, then, again, the chapter refers to a

Chu's campaign against the joint forces of Qin, Qi 齊, Han 韓, and Wei 魏 in 301 B.C.E., while Qin's assault on Yan 漂 (Chu's major stronghold in the middle Han River valley) and on the Chu capital Ying 趴 was conducted in 279-278 в.C.E. The Xunzi which refers to the same events (Xunzi jijie 荀子集解, annotated by Wang Xianqian 王先謙 [18421917] [Beijing: Zhonghua, 1992], 281-83 [“Yi bing” 議兵, X.15]) clearly distinguishes between the two campaigns, while the Book of Lord Shang does not, which may indicate a much later date of composition of that passage.

6o. Shang Yang replaced the aristocratic system of Qin with the new system of ranks of merits, granted in exchange for decapitating enemy soldiers (or purchasable in exchange for grain). See a brief introduction in Yuri Pines et al., "General Introduction: Qin History Revisited," in Birth of an Empire: The State of Qin revisited, ed. Yuri Pines et al. (Berkeley: University of California Press, 2014), 24-25, q.v. further references; cf. Du Zhengsheng 杜正勝, “Cong juezhi lun Shang Yang bianfa suo xingcheng de shehui" 從爵制論商鞅變法所形成的社會, Zhongyang yanjiuyuan lishi yuyan yanjiusuo jikan 中央研究院歷史語言研究所集刊 56.3 (1985), 485-544.

61. This is how the authors of General History of Chinese Economy interpret the sentence (Zhou Ziqiang 周自強, Zhongguo jingji tongshi: Xian Qin jingji juan 中國經濟通史: 先秦經濟卷 [Beijing: Zhongguo shehui kexue, 2007], 1143-44); see also Zhang Jue,

footnote continued on next page 
dispersed mode of rule that characterized the state of Qin before the reform era. ${ }^{62}$ All these suggest that chapter 2 is indeed one of the earliest in the Book of Lord Shang.63

Another possibly early chapter is 12, "Military defense" ("Bing shou" 兵守). It starts with enumerating the difficulties faced by a state that has to combat enemies on the four frontiers; this state has to engage in defensive warfare and compensate for its strategic vulnerability with the ability to utilize its human resources fully. The situation of the state surrounded by enemies on the four sides, and its comparison with another state which backs the sea (presumably Qi 齊), is strongly indicative of the chapter having been written in the state of Wei 魏, where Shang Yang's career started. ${ }^{64}$ If this chapter was indeed produced by Shang Yang or a member of his circle, then it should be a very early product, preceding Shang Yang's departure to Qin in 360 B.C.E. It will also explain the markedly defensive focus of the chapter, which is at odds with other military chapters of the Book of Lord Shang and with the known facts from Shang Yang's biography. ${ }^{65}$

Moreover, comparing the "Military defense" chapter with the socalled defensive chapters of the Mozi composed probably in the latter half of the Warring States period reflects clear differences in the date of their composition. This system of complete mobilization of women, elderly, and the infirm in the Mozi 墨子 appears incomparably more

Shangjunshu, 20, n. 1. In an aristocratic age, nobles could determine the rates of taxation in their allotments (cai yi 采邑); see Zhu Fenghan 朱鳳瀚, Shang Zhou jiazu xingtai yanjiu 商周家族形態研究 (Tianjin: Tianjin guji, 1990), 544-55.

62. The degree of decentralization in Qin is subject to scholarly debate; I accept Yoshimoto Michimasa's view according to which Qin did not differ fundamentally from other polities of the aristocratic Spring and Autumn Periods (Yoshimoto, "Shin shi kenkyū josetsu" 秦史研究序說, Shirin 史林 78.3 [1995], 34-67). For a different view, see Melvin P. Thatcher, "Central Government of the State of Ch'in in the Spring and Autumn Period," Journal of Oriental Studies 23.1 (1985), 29-53.

63. Theoretically it is possible of course that later editors deliberately made the chapter more archaic-looking, but I doubt this is the case: there is simply no visible reason for such manipulation of this otherwise insignificant segment of the Book of Lord Shang.

64. Of course, every state could nominally face enemies on each of its borders, but only Wei and Han were surrounded by equally powerful polities, and Wei was the major victim of coordinated assaults by its four neighbors (Qin, Zhao, Qi, and Chu; see more in Lewis 1999a: 595-96, 634-35). Also, only Wei neighbored a state which "backed the sea," i.e. Qi.

65. It is possible of course that the chapter was unrelated to Shang Yang and misplaced in the Book of Lord Shang by later transmitters. I do not find, however, any reason to support this scenario. 
sophisticated than in the Book of Lord Shang. ${ }^{66}$ The "Military defense" chapter does envision mobilizing everybody, but its recommendations remain very rudimentary (for instance, it emphasizes primarily the need to prevent contacts among the three armies staffed by adult men, by adult women, and by the "elderly and the infirm": but would it be possible to prevent these contacts in the cramped confines of a defended fortress?). It is likely then that the chapter reflects early experiments with complete mobilization of the entire populace to defend the fortress, and that it is datable to the early Warring States period. All these allow the placement of chapter 12 among the earliest in the book.

The third case in which the chapter's content suggests an early date of composition is chapter 6, "Calculating the land" ("Suan di" 算地), one of the ideological centerpieces of the text. The chapter depicts the composition of lands under the Qin's control as follows:

故為國任地者，山林居什一，藪澤居什一，谿谷流水居什一，都邑蹊道居什 $\{\text { 一, 惡田居什二, 良田居什 }\}^{67}$ 四。此先王之正律也。

Hence, in ruling the state and making use of ${ }^{68}$ the land, the correct standard of the former kings was: mountains and forests occupy one-tenth; swamps and marshlands occupy one-tenth; valleys, dales and running rivers occupy one-tenth; towns, settlements, paths and roads occupy \{one\}tenth; \{infertile fields occupy two-tenths, fertile fields occupy\} four\{tenths\}. (6.2)

\section{The text continues:}

\section{小畧五百, 足待一役, 此地不任也。方土百里, 出戰卒萬人者, 數小也。}

The territory of five hundred small $m u$ is enough to provide for one serviceman; [yet] this means that the land is not properly utilized. A territory of one hundred $l i$ squared can provide for ten thousand soldiers: [yet] the number is [still] small. (6.2)

The "correct standard of the former kings" referred to in this text reflects what might have been a standard view of land division in the Loess Plateau during the Warring States period; similar calculations

66. See Robin D. S. Yates. "The Mohists on Warfare: Technology, Technique, and Justification," in Studies in Classical Chinese Thought, ed. Henry Rosemont, Jr., and Benjamin I. Schwartz, Journal of the American Academy of Religion 47.3 (1979), Thematic Issue, 549-6o3, especially pp. 583-85.

67 . The characters in curly brackets are missing from the text and are complemented from the parallel passage in chapter 15.1, following Yu Yue's suggestion.

68. Reading ren 任 here and below in this passage as "to utilize" or "to make use of" following Gao Heng. 
appear in several other texts. ${ }^{69}$ The relatively high proportion of cultivated areas in comparison to mountains and rivers clearly suggests that the text was authored before the Qin conquest of Sichuan c. 316 B.C.E., which radically altered the nature of the terrain under Qin's control (see more below). ${ }^{70}$ Yet what is more important for the text's dating is the author's dissatisfaction with the current situation in which a household possesses 500 small (100 paces long) $m u$ 亩, while $100 \mathrm{li}$ squared (i.e. approximately $1,600 \mathrm{~km}^{2}$ ) could provide only for 10,000 soldiers. ${ }^{71}$ This dissatisfaction is related to one of the important agricultural reforms allegedly initiated by Shang Yang: replacing a small $m u$ with a large one (240 paces long), and the subsequent determination that the standard allotment to one household should be 100 large $m u$ (c. $100 \times 461 \mathrm{~m}^{2}=4.61 \mathrm{ha}$ ) rather than 500 small $m u$ (c. $500 \times$ $192 \mathrm{~m}^{2}=9.6 \mathrm{ha}$ ) under the previous system. ${ }^{72}$ Since we know from the Qin Statute on Land, unearthed from Tomb 50 at Haojiaping, Qingchuan 青川郝家坪 (Sichuan), that by 309 B.C.E. the large $m u$ was the standard measurement of agricultural fields, it is clear that the text of chapter 6 must be considerably earlier. ${ }^{73}$ It may not be too bold to

69. One is the “Wang zhi" 王制 chapter of the Liji 禮記 (Liji jijie 禮記集解, compiled by Sun Xidan 孫希旦 [Beijing: Zhonghua], 392 [XIV.5]), where proportion of arable lands is two-thirds (slightly higher than in the Book of Lord Shang); a similar proportion is cited from the alleged Li Kui's 李悝 (fl. c. 4 OO B.C.E.) regulations (Hanshu 24A: 1124). Elsewhere the Hanshu refers to the situation under Yin 殷 (i.e. Shang 商 [c. 1600-1046 B.C.E.]) and early Western Zhou 西周 (c. 1046-771 в.с.E.), when arable lands constituted only 36 percent of the landmass (Hanshu 23: 1081-82). Li Ling 李零 correctly suggests that the latter number reflected the underdevelopment of agricultural production in the early Zhou period (Li Ling, "Shangjunshu zhong de tudi renkou zhengce yu juezhi” 《商君書》中的土地人口政策與爵制, Guji zhengli yu yanjiu 古籍整理與研究 1991.6, 23-24).

70. Sichuan Basin, of course, is mostly arable, just like the Loess Plateau, but it is separated from the Qin heartland at the Wei River 渭河 valley by a sizable area covered by mountain ranges, in which arable lands are just a tiny proportion of the landmass.

71. One square $l i$ contained 900 small $m u$ ( 300 by 300 paces). One hundred $l i$ squared (i.e. 10,000 square $l i$ ) is then 9 million small $m u$, of which, according to the proportion outlined in the text, six-tenths are agriculturally productive, which means $5,400,000 \mathrm{mu}$. Following the proportion of one serviceman for $500 \mathrm{mu}$, we get 10,800 soldiers, which is close to what the text says (Li Ling, "Shangjunshu," 25).

72. Calculations of $m u$ are based on A. F. P. Hulsewé, Remnants of Ch'in Law: An Annotated Translation of the Ch'in Legal and Administrative Rules of the 3 rd Century B.C. Discovered in Yün-meng Prefecture, Hu-pei Province, in 1975 (Leiden: Brill, 1985), 19. The decrease in size of a standard family plot evidently reflected the increased productivity of Qin agriculture in the aftermath of the introduction of iron tools in the fourth century B.C.E., which allowed higher yields from a smaller plot.

73. For the translation of the Haojiaping Statute see Hulsewé, Remnants, 211-12; for a detailed analysis, see Maxim Korolkov, "Zemel'noe zakonodatel'stvo i kontrol' 
suggest that chapter 6 reflects the situation during the period of the promulgation of Shang Yang's reforms, when a smaller $m u$ was still current in the state of Qin.

\section{B. The Chapter's Language}

Back in 1926, Bernhard Karlgren published his seminal study "On the Authenticity and Nature of the Tso Chuan," in which he explored linguistic differences among several major pre-imperial texts as a possible indicator of their dating and authenticity. This pioneering studydespite its manifold flaws, which were inevitable in an age before concordances and digital resources-became hugely influential, spurring heated debates, and encouraging many follow-ups. ${ }^{74}$ Duyvendak, in particular, attempted to employ Karlgren's method in dealing with the chapters of the Book of Lord Shang, yet his effort did not yield convincing results. Now, almost a century after Karlgren's study, the advance in the field remains minuscule, especially insofar as the Warring Statesperiod literature is concerned. It seems that there are simply no unequivocal grammatical parameters that would allow us distinguish between, e.g., fourth- and third-century-B.C.E. texts. So frustrating is the situation that some scholars came to a simple conclusion: "it is impossible to date pre-Han texts with any degree of accuracy."75

In an earlier study, I tried to find another parameter for temporary changes in the language of pre-imperial texts, namely their specific lexicon. For instance, there are a few terms and compounds which are non-existent in the fifth-century-в.с.Е. texts but become ubiquitous thereafter (e.g. “benevolence and righteousness" [renyi 仁義], "myriad things" [wanwu 萬物], “ten-thousand-chariot-[strong state]" [wansheng 萬乘], or crossbow [ $n u$ 㛎], and crossbow-related terms such as $j i$ 機, "trigger"). Other terms are not attested to before the late fourth century B.C.E., but dominate the third-century-в.C.E. texts: e.g. "pattern" or "principle" (li 理), the pair yin-yang 陰陽 in its meaning of basic cosmic forces or complementary opposites, or the term "plain-clothed" (buyi 布衣, referring to

gosudarstva nad zemlej v epokhu Chzhan'go i v nachale ranneimperskoj epokhi (po dannym vnov' obnaruzhennykh zakonodatel'nykh tekstov)" (Ph.D. thesis, Russian Academy of Sciences, Institute of Oriental Studies, 2010), 76-90.

74. See Bernhard Karlgren, "On the Authenticity and Nature of the Tso Chuan," Göteborgs Hogscholes Årsskrift 32 (1926), 1-65. For a recent example of criticism of Karlgren's methods, see Luo Shaodan 羅紹丹, “Inadequacy of Karlgren's Linguistic Method as Seen in Rune Svarverud's Study of the Xinshu," Journal of Chinese Linguistics 31.2 (2003), 270-99.

75. David Schaberg, A Patterned Past: Form and Thought in Early Chinese Historiography (Cambridge, MA: Harvard University Asia Center, 2001), 315. 
poor members of the shi 士 stratum). Insofar as we speak of terms that became fairly widespread in political and philosophical texts of the late Warring States period, their appearance or the lack thereof may serve as a useful indicator of the text's date. ${ }^{76}$

Back then, I analyzed the language of the Book of Lord Shang, showing that, overall, it corresponds to the fourth-century-B.C.E. layer. ${ }^{77}$ The text never employs such terms as buyi or yin-yang as cosmic forces or binary opposites. The term $l i$ 理 appears only four times, thrice in a single passage in chapter 18, “Charting the policies" (“Hua ce" 畫策) (18.7); overall it seems that, at the time of the compilation of the bulk of the Book of Lord Shang, this term had not yet become common in intellectual discourse. ${ }^{78}$ This allows the tentative conclusion that most of the chapters of the book were composed before c. 300 в.C.E. But can we fine-tune this method to discern the date of individual chapters?

Lexical changes may be a fairly efficient means of distinguishing the date of the composition of the bulk of an ancient text (or its Ur-text), yet their efficiency diminishes when we deal with smaller textual units, such as individual chapters. The very brevity of a chapter (usually around one thousand, and never more than two thousand, characters in the Book of Lord Shang) makes the sample too small to be reliable. The smaller the sample, the greater is the danger that an inadvertent "correction" of an illegible character by, e.g., a Han-dynasty scribe ${ }^{79}$ will add a third-century-B.C.E. character into a fourth-century-B.C.E. text, skewing my results. Nonetheless, with due caution some meaningful lexical differences among the chapters can still be discerned.

One of the most significant differences among the chapters of the Book of Lord Shang is the difference in the ruler's appellations. While most chapters apply the neutral "ruler" (jun 君) and "sovereign" (zhu 主), a few others employ "king" (wang 王), which suggests that they were produced after the appropriation of the royal title by Lord (later King)

76. Yuri Pines, "Lexical Changes in Zhanguo Texts," Journal of the American Oriental Society 122.4 (2002), 691-705.

77. There are several studies of the grammar and the lexicon of the Book of Lord Shang, but none of these seems to be interested in using their data to establish the dating of the text or of its individual chapters. See, e.g., Du Lirong 杜麗容, Shang jun shu shici yanjiu 《商君書》實詞研究 (Ji'nan: Shandong wenyi, 2010); Li Jiequn 李傑 群, Shang jun shu xuci yanjiu 商君書虛詞研究 (Beijing: Zhongguo wenshi, 2000).

78. For the introduction of the term $l i$ into the philosophical discourse of the Warring States period, see Sato Masayuki 佐藤將之, Xunzi lizhi sixiang de yuanyuan yu Zhanguo zhuzi zhi yanjiu 荀子禮治思想的淵源與戰國諸子之研究 (Taida zhexue congshu 8; Taibei: Taida chuban zhongxin, 2013)，177-235; Deng Guoguang 鄧國光， Jingxue yi li 經學義理 (Shanghai: Shanghai guji, 2011).

79. Allan, Buried Ideas, 23-24. 
Huiwen of Qin 秦惠文王 in 325 в.C.E. In addition to chapter 15, the lateness of which has been clarified already, these include chapter 17 , "Rewards and punishments" ("Shang xing" 賞刑), and possibly chapter 19, "Within the borders" ("Jing nei" 境内), although in this latter case the appearance of the term wang is disputed. ${ }^{80}$ Chapter 26 speaks of the ruler as a "Son of Heaven" (tianzi $i$ 子), which adds yet another indication of its provenance around the age of the imperial unification of 221 B.C.E. ${ }^{81}$

Variations in the ruler's appellations bring us to another interesting difference among the chapters of the Book of Lord Shang: their preoccupation with the concept of the True Monarch. As I have argued elsewhere, from the Middle Warring States period on, many texts focus on this figure of an ideal ruler who will be able to unify All under Heaven under his aegis and bring about universal peace and stability. ${ }^{82}$ The Book of Lord Shang is one of the earliest texts in which this notion figures prominently; yet the intensity of discussion differs considerably among various chapters. Some chapters, most notably 3, "Agriculture and warfare" (“Nong zhan" 農戰), and 4, “Eliminating the strong," as well as those related to chapter 4 (see below), abound with promises for a ruler who would heed the authors' advice to become the True Monarch; in others, including all the identifiably late chapters, these pronouncements disappear. It is likely that the difference again revolves around 325 B.C.E.: after the Qin rulers adopted the title king/monarch (wang 王), it was no longer politically advisable to emphasize the ruler's need to become a True Monarch, which would imply that his current title was fraudulent. This suggests that chapters 3 and 4 and a few others, such as 7 , "Opening the barred," represent ideas and knowledge of the mid-fourth century в.С.Е.

A word of caution is needed here. Lexical changes can rarely be used with precision, and they leave much room for doubt. A good case of such doubt is chapter 18 of the Book of Lord Shang. On the one hand,

80. The crucial issue for the chapter's dating is whether or not its last section (19.9) refers to a General Inspector (zheng yushi 正御史) or to a Royal Inspector (wang yushi 王 御史); since no fewer than ten recensions use zheng 正 (Zhang Jue, Shangjunshu, 235), this usage seems more appropriate.

81. Recall that Qin rulers did not call themselves tianzi (this term referred exclusively to the Zhou kings prior to the dynasty's final demise in 256 в.C.E.). Whether or not the Qin kings on the eve of the imperial unification or in its aftermath tried to appropriate this self-appellation is debatable.

82. The concept of the True Monarch is distinguished from that of a regular "king" by the usage of the term wang as a verb ("to act as [or become] a [true] monarch"), by the topicalization wang zhe 王者, by the notion of the Monarch's Way (wang dao 王道), and the like (see Yuri Pines, Envisioning Eternal Empire: Chinese Political Thought of the Warring States Era [Honolulu: University of Hawai'i Press, 2009], 229, n. 5). In the Book of Lord Shang, the verbal usage of the term wang prevails. 
its fondness for the term $l i$ (pattern, principle), which appears there thrice (18.8), is indicative of a relatively late date: no earlier than the late fourth century в.C.Е., which is the dividing line for the sudden outburst in the usage of $l i$ in philosophical texts. On the other hand, this chapter employs the term wang as a verb, in a mode which is reminiscent of earlier chapters of the Book of Lord Shang (18.3). Possibly, the composite nature of this chapter explains why passages composed at different periods appear side-by-side here. In any case this chapter, and several other chapters, lack clear lexical indicators that would help to determine their dating. More studies need to be done to advance our understanding of linguistic or lexical changes in Warring States-period texts, and to allow meaningful employment of this method.

\section{Interrelations among the Chapters}

The Book of Lord Shang is not a haphazard collection of disparate treatises; its chapters share not only fundamental ideas but even whole chunks of text, from one or two sentences to lengthy passages. These interrelations are often assumed to indicate the proximity in the chapters' date of composition, ${ }^{83}$ but this is not necessarily the case. In some cases it is conceivable indeed that two similar or identical chunks of texts were put by a single person into two more-or-less simultaneously composed essays (just like a modern scholar can repeat the same passage in two or more articles). This may serve as a plausible explanation for similarities among a few sections in the Book of Lord Shang (e.g. almost verbatim repetitions of 3.5 in 4.3 , of 3.7 in 4.5 , or what appears a direct citation of a sentence from 6.6 in 7.2 preceded by "therefore it is said" 故曰). Yet it is equally possible that similar paragraphs were assembled into composite chapters by later editors (which may be the case of parallels between chapter 4 and 13 , for instance). Moreover, as I shall demonstrate below, at times an almost identical textual segment can serve quite different ideological needs in two different chapters. Yet on other occasions an apparent similarity among a few chapters may reflect more complex patterns of intellectual development within "Shang Yang's school."

One of the most interesting features of the Book of Lord Shang is the existence of several clusters of chapters which are related to each other. In each of these clusters we may discern earlier and later chapters. The clearest instance is the cluster of three chapters: 4 , "Eliminating the strong"; 20, "Weakening the people"; and 5, "Explaining the people"

83. See, e.g., Rong Zhaozu "Shangjunshu"; Zheng Liangshu, Shang Yang. 
(“Shuo min” 說民). As was demonstrated by Meng Jifu 蒙季甫， the two latter chapters provide a line-by-line exegesis of the former. ${ }^{84}$ It is not clear why the exegesis was divided into two chapters, or why the final sections of chapter 4 remain without exegesis, but the "canoncommentary" (sometimes called jingshuo 經說) relation among the three chapters is undeniable. It seems that chapter 4 was conceived as a canonical text, probably a summa of Shang Yang's wisdom, which deserved special commentarial treatment. ${ }^{85}$ Clearly, then, chapter 4 is earlier than its two exegetical chapters, and it is likely that it belongs to an earlier layer of the Book of Lord Shang.

To the cluster centered on chapter 4, we should add chapter 13, which is closely related to chapter 4 , and which is reproduced to a large extent in chapter 53 of Han Feizi. The relations between the three have been analyzed by Zheng Liangshu, who demonstrated convincingly that chapter 4 is earlier, chapter 13 is later, and chapter 53 of the Han Feizi is derivative of chapter 13 of the Book of Lord Shang. I shall not repeat Zheng's detailed analysis, the basic parameters of which I accept; but my conclusion differs slightly from his. ${ }^{86}$ I think that chapter 13 may be an alternative version of chapter 4 ; a kind of a draft that is less organized than chapter 4 , less forceful in its style, and also is less abusive in its rhetoric. Possibly it is a composite chapter, which contains segments of chapter 4 and later additions. What matters for our discussion of the

84. Meng Jifu 蒙季甫, “Shang jun shu 'Shuo min' ‘Ruo min' pian wei jieshuo 'Qu qiang' pian kanzheng ji" 《商君書〉〈說民〉〈弱民〉篇為解説〈去強〉篇刊正記. Tushu jikan 圖書集刊 1 (1942).

85. The existence of internal exegesis is not peculiar to the Book of Lord Shang; it is represented, for instance, by the Wu xing 五行 text discovered both in Tomb 1 , Guodian 郭店 (Hubei) and Tomb 3, Mawangdui 馬王堆 (Hunan); the second of these provided exegesis to the first (Pang Pu, "A Comparison of the Bamboo Slip and the Silk Manuscript Wu Xing," Contemporary Chinese Thought 32.1 [2000], 50-57). For more parallels, see, e.g., chapters “Ban fa" 版法 and “Ban fa jie" 版法解 or "Xing shi" 形勢 and “Xing shi jie" 形勢解 of the Guanzi 管子 or jing 經 and shuo 說 chapters of the Mozi.

86. See Zheng Liangshu, Shang Yang, 82-103. Zheng's detailed textual analysis cannot be repeated here in full; suffice it to illustrate its correctness with a single example. All the three chapters tell the ruler that if he heeds the author's advice he will either become Monarch (wang 王) or become powerful (qiang 強); if he fails, his state will be dismembered (xiao 削). This wang-qiang-xiao (or, more often wang-qiangwang 亡 [to be ruined]) sequence recurs throughout many chapters of the Book of Lord Shang but not in the Han Feizi; clearly then the latter borrows a chapter from the former and not vice versa. See also Mozawa Michinao 茂澤方尚, “Kanpishi 'Chokurei' hen to Shōkunsho 'Kinrei' hen' ryōhen no zengo kankei ni tsuite" 『韓非子』「飭令」 篇と『商君書』「靳令」篇——両篇の前後関係について, Komazawa shigaku 駒澤史學 43 (1991), 1-23. Mozawa's analysis differs from Zheng, but he also concludes that both chapters were produced by the followers of Shang Yang. 
chapters' dating is that chapter 4 clearly belongs to an earlier stratum than three others, while each of these three reflects attempts by anonymous members of "Shang Yang's school" to explicate some of the enigmatic statements of chapter 4, but also, at times, to moderate its harsh messages. ${ }^{87}$

Another, less evident, cluster comprises the three chapters that deal with land utilization: 2, 6, and 15. Rong Zhaozu, who noticed their similarities, opined that they were authored simultaneously, and dated all of them to post-250 B.C.E., because this is the unequivocal terminus ante quem non for chapter $15 .{ }^{88} \mathrm{~A}$ more careful reading of these chapters not only undermines this uniform dating, as I have demonstrated above, but also calls for more caution when comparing ostensibly similar accounts. For instance, section 15.1 repeats almost verbatim the depiction of a supposedly standard land division from chapter 6.2 (cited above). Yet while in 6.2 the division of land in which 6o percent of the territory is arable is considered a norm, the authors of chapter 15 complain bitterly that "arable lands are just two-tenths" of the territory under Qin's control. ${ }^{89}$ In all likelihood, this reflects the new realities in the aftermath of Qin's expansion into Sichuan and the Han River valley between 316 and 278 в.C.E. In the mountainous terrain of these areas, the old divisions based on Loess Plateau realities no longer worked. Moreover, the two accounts also reflect sharply different densities of population. In 6.2, a unit of $100 \mathrm{li}$ squared is supposed to provide for 10,000 soldiers ( $z u$ 卒) or servicemen ( $y i$ 役), which refers to 10,000 households or about fifty thousand people. In chapter 15.1, in contrast, the same territory is occupied by 50,00o laborers (zuo fu 作夫), the term which refers to every able-bodied man or woman (aged 15 to 60), who constituted 60-70 percent of household members. In this case, we can speak of $70-80,000$ expected inhabitants of a unit of 100 li squared: a $40-60$ percent rise in the population in the wake of increased agricultural productivity in the second half of the Warring States period.

These differences are revealing. They not only provide additional proof for the relative earliness of chapter 6 and a post-26o в.C.Е. composition of chapter 15 , but also show how the same paragraph in two chapters may be utilized to convey different ideas and can reflect different realities. This warns against simplistic attempts to consider similarity

87. See further in Pines, "Alienating Rhetoric."

88. Rong Zhaozu, "Shangjunshu."

89. It is unclear whether “arable lands" ( $g u t u$ 谷土) refers here to all the fields (6o percent of the normative territorial unit) or only to fertile fields (4o percent of the unit). 
between the two chapters as immediately reflecting their closeness in terms of authorship and dates. ${ }^{90}$

The third, and less obvious, cluster consists of military chapters (1012 and 19), which are dedicated to practical issues of combat. As these chapters (especially 10 and 11) are very badly damaged, it is difficult to discuss the nature of their interconnectedness. However, a comparison between chapters 12 and 19 is revealing. Both discuss siege warfare, but the differences are huge. Chapter 12, "Military defense," focuses on a purely defensive strategy. It shows how the full mobilization of the besieged will nullify the advantages of the assaulting army, and doom this army to inevitable failure. In marked distinction, chapter 19 is concerned with a purely offensive strategy. The attackers will overpower the defenders thanks to the proper use of positive incentives for valiant head-cutters and sappers, who will undermine the enemy's walls. The differences could not be greater. They strongly suggest that chapter 19 could not have been produced at a very early stage of the composition of the Book of Lord Shang, as is often proposed, ${ }^{91}$ though it is still possible that it was authored by Shang Yang. Examining other chapters in the same treatise from a comparative perspective may thus allow us to correct many arbitrary conclusions.

\section{Intellectual and Stylistic Consistency}

Descending the ladder of reliable dating criteria, we come now to the issue of intellectual and stylistic differences among the chapters. Scholars have long noticed that while the Book of Lord Shang is fundamentally consistent in its outlook and, to a lesser extent, in its style, there are still observable differences among the chapters that can be employed to fine-tune their dating. In particular, Zheng Liangshu and Yoshinami Takashi used these differences to outline the evolution of the views of "Shang Yang's school."92 Yet while I do accept the validity of much of their analysis, I think that many of their conclusions were premature.

There are several problems with focusing excessively on the book's intellectual and stylistic consistency or the lack thereof. First, what

90. Yoshinami Takashi 好并隆司 in a perceptive study ("Shōkunsho Raimin, Sanchi ryōhen yori mita Shinchō kenryōku no keisei katei" 商君書徠民、算地兩篇よりみた秦 朝權力の形成過程, Tōyōshi kenkyū 東洋史研究 44.1 [1985], 1-22) noticed differences in ideological emphases between chapters 6, and 15; and while some of his discussion is overtly speculative, overall his analysis is convincing.

91. See, e.g., Zheng Liangshu, Shang Yang, 20-23; Tong Weimin, Chutu wenxian, 190-99.

92. Zheng Liangshu, Shang Yang; Yoshinami, "Shōkunsho" and Shōkunsho. 
exactly constitutes "consistency" is hard to measure. Some parameters that one scholar may consider important may be rejected by another. For instance, Zheng Liangshu observed what he took to be an essential divide in the Book of Lord Shang between chapters (e.g. 14, 17) that emphasize the need to combine harsh punishments for wrongdoers with lavish rewards for meritorious soldiers and tillers, and other chapters (e.g. 4 and those of its cluster, as well as chapters 7,8 , and 18) that advocate harsh punishments but minimal rewards. For Zheng, these differences suggest that the second group of chapters was not produced by Shang Yang and does not reflect his views. ${ }^{93}$ This is a questionable assumption, not only because it is based on a highly tendentious interpretation of the "real Shang Yang's thought," as supposedly reflected in Sima Qian's biography of Shang Yang, but also because the very issue of a proper balance between punishments and rewards was not necessarily a major point of discord among Shang Yang's followers. Authors could modify their recommendations in different circumstances and when facing different audiences, without feeling that they deviated from fundamental views which focus on rewards and punishments as the two handles through which the populace could be manipulated.

Second, even when differences among the chapters are undeniable, these do not necessarily mean that the chapters were produced by different authors. Recall that books associated with the leading thinkers of the Warring States period were not produced as coherent treatises. Rather, they typically represent something akin to the collected oeuvres of a thinker: a combination of different essays composed in different circumstances at different stages of a thinker's life, and to which works by a thinker's disciples and followers were usually added. Even among the chapters penned by a single thinker, differences can be expected. An author could improve his style and modify his views during his career; or he could adapt the style and the content of his proposals to meet specific demands of the chapter's addressees. Paul R. Goldin's insightful observation that different emphases in different chapters of the Han Feizi may reflect different audiences targeted by each of the chapters is equally valid for the Book of Lord Shang. ${ }^{94}$ Demanding complete ideological and stylistic uniformity in these chapters is then incongruous. It becomes counterproductive when scholars first presuppose

93. Zheng Liangshu, Shang Yang, 35-40.

94. Paul R. Goldin, After Confucius: Studies in Early Chinese Philosophy (Honolulu: University of Hawai'i Press, 2005), 58-65; and Goldin, "Han Fei and the Han Feizi," in Dao Companion to the Philosophy of Han Fei, ed. Paul R. Goldin (Dordrecht: Springer, 2013), 1-21. 
how the text evolved ideologically and then date individual chapters. The result is inevitably speculative, and at times fairly misleading. ${ }^{95}$

Speaking of the text's literary qualities, scholars such as Zheng Liangshu presuppose a kind of neat stylistic progress from earlier unpolished chapters of the Book of Lord Shang, such as 2 and 19, to more literally engaging chapters such as 17,15 , or 24 . The difference between the two groups is undeniable: for instance, while chapter 2 is dull and repetitious, ${ }^{96}$ the latter chapters are better structured and employ a much broader repertoire of argumentative techniques. Yet while it is plausible that chapters composed at a later stage of the Book of Lord Shang's formation would develop more articulate argumentation, ${ }^{97}$ it is equally possible that differences in style reflect individual preferences and skills of the chapters' authors. Any attempt to date the chapters purely on the basis of stylistic criteria will remain highly speculative.

It is equally difficult to use differences in the chapters' content as a tool for determining the date of their composition. For instance, no fewer than three chapters ( 7 , "Opening the barred," 18 , "Planning policies," and 23, "Ruler and minister" ["Jun chen" 君臣]) narrate how the state was formed at the dawn of human history. The first two chapters presuppose the existence of maintainable social order in a primeval stateless society; it is just that accelerating demographic growth made this order unsustainable. Chapter 23, in contrast, associates stateless society with intrinsic violence and turmoil, which can be overcome only through the creation of political and social institutions. This latter version is closer to the mainstream views of Warring States-period thinkers. But does it represent an earlier approach of the book's authors, as argued by Yoshinami, or a later one, as assumed by Zheng Liangshu?98

95. One can immediately think of similar speculative debates about the supposed evolution of the ideas in the Mozi 墨子 core chapters (see the summary of these debates in Defoort and Standaert, "Introduction"; cf. Li Rui, "Xian Qin," 144-46).

96. Chapter 2 comprises twenty short recommendations about how to push the population toward farming: each briefly introduces the desired policies, summarizes their social effects, and concludes with the uniform desideratum: "then wastelands will surely be cultivated" (則草必墾矣). There is no visible logic in the internal organization of the twenty items, and their reasoning about the effects of the proposed actions is at times difficult to follow. This type of perfunctory argumentation does not recur elsewhere in the Book of Lord Shang.

97. For increasing articulation of philosophical discourse in the second half of the Warring States period, see Sato, The Confucian Quest, 108-62.

98. See respectively Yoshinami, Shōkunsho, 341-43; Zheng Liangshu, Shang Yang, 121-23; for a general discussion of the Warring States-period views of the state evolution, see Yuri Pines and Gideon Shelach, "'Using the Past to Serve the Present': 
Any answer will remain merely a scholar's educated guess. We simply lack sufficient data to decide.

Elsewhere, however, differences in the chapters' content may indeed presuppose evolution of the authors' views, as is the case with administrative thought in the Book of Lord Shang. The issues of proper maintenance of the bureaucratic apparatus and of ruler-minister relations are generally of little interest to the authors of all the identifiably early chapters. These chapters do discuss the policy of appointment to government positions, but this is done exclusively through the prism of its impact on the population's motivation to engage in agriculture and warfare rather than its importance for preserving the ruler's authority vis-à-vis scheming ministers, as would be the case, e.g., in Han Feizi. Administrative issues are raised primarily in chapters 24 and 26 and to a lesser extent in chapters 14, "Cultivation of authority" ("Xiu quan" 修權), and 25, "Attention to law" ("Shen fa" 慎法). My personal feeling is that these chapters may belong to the later stratum of the Book of Lord Shang, but I do not have sufficiently compelling arguments to make this assessment convincing.

\section{E. Relations to Other Texts}

One final possible criterion employed to date the book and its chapters is identifying potential influences by other thinkers. Many Republicanperiod scholars, and some of the later ones (e.g. Zheng Liangshu and Yoshinami Takashi), argued that certain chapters bear an imprint of, e.g., Mengzi 孟子 (c. 380-304 B.C.E.), Laozi 老子, Xunzi 荀子 (c. 310230 B.C.E.), Shen Buhai 申不害 (d. 337 B.C.E.), Shen Dao 慎到, and Han Fei. Accordingly, they postulated that the chapters under discussion post-date those thinkers' lifetimes. What exactly constitutes a proof of "external influence" is not well defined though. For some, it means fundamental ideological impact; thus, Yoshinami considers Shang Yang's ideal of "eradicating punishments with punishments" as a reflection of Laozi's notion of "non-action" (wu wei 無爲). ${ }^{99}$ For others, discovering a certain term in a chapter of the Book of Lord Shang is sufficient to claim its association with a putative inventor or promoter of this term. Thus, shi 勢 (positional power, or power of authority) is associated with Shen Dao; shŭ 數 (method), and shù 術 (technique) are associated with Shen Buhai; the term $y i$ 義 (righteousness, dutifulness, justice) is

Comparative Perspectives on Chinese and Western Theories of the Origins of the State," in Genesis and Regeneration: Essays on Conceptions of Origins, ed. Shaul Shaked (Jerusalem: The Israel Academy of Science and Humanities, 205), 127-63.

99. Yoshinami, Shōkunsho, 343. 
considered to reflect the impact of Mengzi, while the character cheng 誠 (sincerity) is seen as related to the Confucian text "Doctrine of the Mean" (“Zhong yong" 中庸). ${ }^{100}$

None of these assertions appears convincing to me. For instance, the idea of "eradicating punishments with punishments" is broadly shared by many texts, and is traceable even to the canonical Classic of Documents (Shujing 書經); ${ }^{101}$ surely it cannot be reduced to Laozi's influence alone. Even less tenable is Zheng Liangshu's (and his predecessors') identification of key terms in the Book of Lord Shang as reflective of other thinkers' influence. Terms of political and ethical discourse were normally utilized by more than one thinker (for instance, $y i$ is an important term in the Mozi, i.e. it gained prominence long before the Mengzi); hence the very postulation that term $X$ is reflective of an impact by thinker $Y$ is simplistic. Besides, even if the impact of a certain thinker or text on the Book of Lord Shang can plausibly be assumed, this does not necessarily help in dating chapters of the Book of Lord Shang because the dating of the oeuvres of other pre-imperial thinkers remains equally contestable.

We do have parallels, however, between the Book of Lord Shang and a few other texts, such as Laozi (possibly referred to in 17.4 and 18.7) or Guanzi (paralleled, e.g., in 17.4, 23.3), but these parallels cannot help much in determining the chapters' dates simply because the dates of Laozi and Guanzi themselves are difficult to verify. On two occasions, the Book of Lord Shang apparently cites Xunzi (20.11) and Shenzi (i.e. Shen Dao, 26.5); both cases, though, are from demonstrably late textual segments and the citations themselves help little in fine-tuning these chapters' date. Of greater interest is chapter 10, "Methods of war" ("Zhan fa" 戰法), which appears to be engaged in intensive dialogue with the Sunzi 孫子. ${ }^{102}$ Yet given the ongoing debate on the date of the Sunzi's composition, we cannot use this information to assert when chapter 10 was penned. Finally, we may ask whether or not chapter 24 reflects the impact of Shen Dao and Shen Buhai. On the one hand, this chapter is the only one in the Book of Lord Shang to

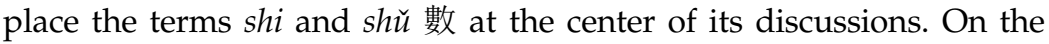
other hand, as noticed above, the very supposition that these terms are derivative from Shen Dao and Shen Buhai respectively is debatable; it is equally plausible that the prominence of both terms in chapter 24

100. Zheng Liangshu, Shang Yang.

101. Charles Sanft, "Concepts of Law in the Shangshu," in The Classic of Documents and the Origins of Chinese Political Philosophy, ed. Martin Kern and Dirk Meyer (Leiden: Brill, forthcoming).

102. See Yuri Pines, "A 'Total War'? Rethinking Military Ideology in the Book of Lord Shang," Journal of Chinese Military History 5.1 (2016) (forthcoming). 
reflects their general importance in the administrative thought of the Warring States period (recall that chapter 24 is one of the very few to focus exclusively on administrative issues). None of the cases above allows us to improve the dating of chapters and sections involved.

\section{Preliminary Conclusion}

Let us summarize our findings. First, it is clear that the Book of Lord Shang as a whole was produced before the imperial unification of 221 B.C.E. (the only possible exception being chapter 26). Second, the text's lexicon suggests that the bulk of it came from the fourth century B.C.E. Third, it is clear that the formation of the text was a result of a lengthy period of accretion which started in Shang Yang's lifetime and ended more than a century after his death. Let us now turn to individual chapters and their precise location within this time span.

We can date with relative precision two chapters $(2,12)$ to the earliest stage of Shang Yang's career, i.e. prior to and on the eve of his reforms in Qin (c. 360 B.C.E.). Other chapters which may come from Shang Yang's lifetime, and quite possibly from an early stage of his career, are 3 and 4. Chapters 6 and 7, the ideological centerpieces of the entire book, are probably later, but were in all likelihood penned during Shang Yang's lifetime or shortly thereafter. Chapters 13,20, and 5 (all of which are related to chapter 4) were surely composed sometime after chapter 4, but we have no clear date of composition (aside from the separate section 20.11 , which certainly came decades after 278 в.C.E.). The military chapters 10 and 11 , as well as 19, definitely come from the fourth century B.C.E., as is suggested by their unawareness of the use of cavalry, but their precise dating is less clear.

Among the identifiably later chapters, the two latest ones $(15,26)$ are safely datable to the final decades before Qin's imperial unification in 221 B.C.E. Chapter 9 is likely to post-date 306 B.C.E., while chapter 17 surely dates from after 325 B.C.E. For no other chapter is decisive dating possible. Some chapters (e.g. 18) are composite in nature, and therefore speaking of a date for their composition is meaningless. Other chapters are either too short $(8,22,23)$, or lack unequivocal indicators of the date for their composition $(14,24,25)$. My tentative results are summarized in Table 1 in the Appendix below.

\section{Epilogue: Hierarchy of the Dating Criteria}

Above, I focused on the determinants of the Book of Lord Shang's dating proposed in earlier studies and tried to arrange them according to the degree of their importance. In particular, I argued that historical 
information contained in the text should be given a clear priority over other criteria in ascertaining the date of the text's composition. To demonstrate the potential usefulness of this claim to other Masters' texts, I want to focus briefly on an example that shares many similarities with the Book of Lord Shang, viz. the Mozi. Like the Book of Lord Shang, Mozi was neglected for almost two millennia before it was rediscovered by Qing philologists; it also suffers from considerable textual corruption; and most notably it is yet another instance of an "evolving text" in which different temporary layers can be discerned. Similarities aside, in recent decades Mozi has attracted an incomparably greater amount of attention from Western scholars than has the Book of Lord Shang; in particular, the relations among the triplet chapters that constitute its core were discussed repeatedly. ${ }^{103}$ It is these debates that I want to address briefly below. Normally, the discussants point out distinctions between the chapters' vocabulary and in their usage of certain grammatical particles to postulate different authorship; then they turn to the chapters' philosophical content as the primary indicator of the sequence of their composition. Without ruling out the importance of this line of investigation, I want to point out its major weakness: namely, ignoring Mozi's historical information as the most reliable criterion for the date of the chapters' composition.

Take for instance chapter 19, the third in the "Contra aggression" ("Fei gong 非攻") triplet. Not a few scholars have opined that it was likely to have been written later than the two other chapters of the triplet, dating it to the middle or end of the fourth century в.С.E. ${ }^{104}$ Regrettably, the discussants ignored a singularly significant piece of historic information in this chapter. The chapter cites Mozi's anonymous rivals who argue that, contrary to Mozi's claims, the states of $\mathrm{Chu}$, Yue 越, Jin, and Qi benefited from aggressive warfare: hence, despite their humble beginnings, they were able "to divide All-under-Heaven into four parts and possess it" (si fen tianxia er you zhi 四分天下而有 之). ${ }^{105}$ This list of four superpowers is puzzling. While Chu, Jin, and Qi were indeed the major powers from the Spring and Autumn Period (Chunqiu 春秋, 770-453 B.C.E.) on, inclusion of Yue, as well as

103. These discussions are summarized in Defoort and Standaert, "Introduction," q.v. for further references.

104. See the summaries of earlier views in Defoort and Standaert, "Introduction," 9-19; see also Paul van Els, "How to End Wars with Words: Three Argumentative Strategies by Mozi and His Followers," in The Mozi as an Evolving Text, 69-94; Karen Desmet, "All Good Things Come in Threes: A Textual Analysis of the Three-fold Structure of the Mohist Ethical Core Chapters" (Ph.D. dissertation, KU Leuven, 2007), 124-49.

105. Mozi V.19: 221 [“Fei gong xia”]. 
exclusion of Qin, are exceptional to the Mozi. ${ }^{106}$ The Qing commentator Su Shixue 蘇時學 (1814-1874) noted this peculiarity and directly related it to the text's dating, suggesting that Mozi did not witness the age of the Warring States when Yue declined, while Qin reappeared as the major power. ${ }^{107}$

Newly available data confirm Su's insight. The recently published bamboo manuscript Xinian 繫年 from the Tsinghua (Qinghua 清華) University collection narrates the history of the late fifth century, showing that then four major powers indeed competed for supremacy under Heaven: the Jin-Yue axis fought (successfully) against the QiChu axis. It was then that the state of Qin, plagued by internal struggles, reached the nadir of its power. ${ }^{108}$ This peculiar situation lasted until the first decades of the fourth century B.C.E., by which time Jin was finally partitioned among its component states of Wei, Han 韓, and Zhao; Yue declined, while Qin restored its fortunes. This means that the situation narrated in the Mozi existed only during Mozi's lifetime (c. 460-390 B.C.E.) and in its immediate aftermath. Were a middle- or late fourthcentury follower to have invented the chapter, or were it to have been heavily edited then, one might expect that the list of major powers would be altered, or at the very least Mozi would be attributed with prescience about Yue's imminent decline. That this is not the case suggests that chapter 19, and other chapters that speak of Yue's power, are closer to Mozi's lifetime and are more reliable in reproducing the Master's views than is often assumed.

A single example, of course, does not account for a full-fledged dating methodology, but it suffices to show that a discussion of the dates of a Masters' text should start with analyzing the text's content from the angles of political, military, administrative, economic, social, or legal history; only then can other criteria be considered. While it is always possible that a later forger would try to create an archaic-looking text, either by resorting to archaizing language, ${ }^{109}$ or by utilizing historical

106. In chapter 18, Mozi mentions Wu 吳 rather than Yue among the four superpowers (along with Chu, Jin, and Qi) (Mozi jiaozhu 墨子校注, compiled and annotated by Wu Yujiang 吳毓江 [1898-1977] [Beijing: Zhonghua, 1994], 203 [V.18, “Fei gong zhong"]); commentators agree that this is a mistake for Yue, as Wu's demise is narrated in the same chapter (note that in the mid-fifth century в.C.E., Yue moved its capital to the former $\mathrm{Wu}$ capital, which may be a reason for its appellation as $\mathrm{Wu}$ ). For adding Yue to the list of superpowers, see also Mozi, 265 (VI.25, “Jie zang 節葬 xia").

107. Mozi jiaozhu, 242, n. 136.

108. See especially sections $19-23$ of Xinian. For Qin's domestic struggles that caused its temporary decline, see Shi ji 5. 199-200.

109. David Schaberg, "Speaking of Documents: Shu Citations in Warring States Texts," in Origins of Chinese Political Thought. 
facts from the past, the evidence suggests that it would be all but impossible for him to truthfully recreate the realities of the long bygone age. ${ }^{110}$ Besides, as the richness of recently unearthed documents allows us to grasp details of sociopolitical developments during the Warring States period incomparably better than was previously possible, we can now evaluate with greater accuracy the dates of the texts' composition. Only after a text's historical content was taken into consideration can we move to its linguistic peculiarities, and then to differences among its chapters and their relations to other texts. Each of these criteria is, in turn, superior to the focus on the text's ideological content as a determinant of its dating.

To be sure, the sequence of the dating criteria outlined above has its limits. For instance, it fits well those texts that abound with historic information, but not those which focus on, e.g., ethical or metaphysical questions and do not contain verifiable historical data. Nor have I addressed a complex problem of the later transmitters' impact on the text's content. Some scholars stress the magnitude of this impact, 111 yet their arguments will remain insufficiently convincing unless they consider the text's historical information and the (im)possibility that it was forged by a later transmitter. More challenging are the instances of adding small but ideologically important segments to an earlier text, as is the case, for instance, with the Zuo zhuan: ${ }^{112}$ these tiny additions can considerably skew my analysis. Historical information aside, much progress should be made before we are able to determine grammatical or lexical changes in pre-imperial texts with sufficient precision. Many problems related to the texts' dating will remain unresolved for the time being. Yet insofar as my discussion above may contribute toward renewed interest in this issue, then the major goal of the present article will be achieved.

110. A clearest example of such a failure are the quasi-historical chapters of the Guanzi, most notably "Da kuang" 大匡 and “Xiao kuang" 小匡 (the latter is related to the "Qi yu" 齊語 section of the Guoyu 國語). While these do reproduce certain events from the lifetime of historical Guan Zhong 管仲 (d. 645 B.C.E.), they overall embed these in the realities of the middle to late Warring States period.

111. Michael Hunter, "Did Mencius Know the Analects?," T'oung Pao 100.1-3 (2014), 33-79.

112. For Gu Jiegang's attempt to distinguish later interpolations in the Zuo zhuan, see Gu Jiegang 顧頴岡川, Chunqiu sanzhuan ji Guoyu zhi zonghe yanjiu 春秋三傳及國語 之綜合研究, ed. Liu Qiyu 劉起釬 (Chengdu: Bashu, 1988). For my summary of these interpolations, see Yuri Pines, Foundations of Confucian Thought: Intellectual Life in the Chunqiu Period, 722-453 B.C.E. (Honolulu: University of Hawai'i Press, 2002), 233-46. 


\section{Appendix}

Table 1. Dates of Individual Chapters of the Book of Lord Shang*

\begin{tabular}{|c|c|c|}
\hline Chapter & Dating & Comments \\
\hline $\begin{array}{l}\text { 1. Revising the laws (更 } \\
\text { 法) }\end{array}$ & $\begin{array}{l}\text { pre-300 } \\
\text { B.C.E.? }\end{array}$ & $\begin{array}{l}\text { May be based on authentic records of } \\
\text { the start of Shang Yang's career in } \\
\text { Qin }\end{array}$ \\
\hline $\begin{array}{l}\text { 2. Orders to cultivate } \\
\text { wastelands (墾令) }\end{array}$ & $\begin{array}{l}\text { pre- } 350 \\
\text { B.C.E. }\end{array}$ & $\begin{array}{l}\text { Probably from the earliest stages of } \\
\text { Shang Yang's reforms in Qin }\end{array}$ \\
\hline $\begin{array}{l}\text { 3. Agriculture and } \\
\text { warfare (農戰) }\end{array}$ & $\begin{array}{l}\text { pre-350 } \\
\text { B.C.E.? }\end{array}$ & $\begin{array}{l}\text { Earliness suggested by the verbal } \\
\text { usage of the term wang and by a } \\
\text { relatively unpolished style }\end{array}$ \\
\hline $\begin{array}{l}\text { 4. Eliminating the } \\
\text { strong (去強) }\end{array}$ & $\begin{array}{l}\text { pre-350 } \\
\text { B.C.E.? }\end{array}$ & $\begin{array}{l}\text { Earliness suggested by the verbal } \\
\text { usage of the term wang and by a } \\
\text { relatively unpolished style; the } \\
\text { chapter is designed as Shang Yang's } \\
\text { "canon" }\end{array}$ \\
\hline $\begin{array}{l}\text { 5. Explaining the people } \\
\text { (說民) }\end{array}$ & $\begin{array}{l}350-300 \\
\text { B.C.E.? }\end{array}$ & Exegesis on chapter 4 \\
\hline $\begin{array}{l}\text { 6. Calculating the land } \\
\text { (算地) }\end{array}$ & $\begin{array}{r}350-330 \\
\text { B.C.E.? }\end{array}$ & $\begin{array}{l}\text { Philosophically mature; economic data } \\
\text { comes from considerably earlier } \\
\text { than } 309 \text { в.C.E. }\end{array}$ \\
\hline $\begin{array}{l}\text { 7. Opening the blocked } \\
\text { (開塞) }\end{array}$ & $\begin{array}{r}350-330 \\
\text { B.C.E.? }\end{array}$ & $\begin{array}{l}\text { Philosophically mature; related to } \\
\text { chapter 6; earliness suggested by the } \\
\text { verbal usage of the term wang }\end{array}$ \\
\hline $\begin{array}{l}\text { 8. Speaking of the One } \\
\text { (壹言) }\end{array}$ & $\begin{array}{r}350-330 \\
\text { B.C.E.? }\end{array}$ & $\begin{array}{l}\text { Too short to determine but is very } \\
\text { close in content to chapters } 6 \text { and } 7 \text {, } \\
\text { the major points of which it } \\
\text { summarizes }\end{array}$ \\
\hline $\begin{array}{l}\text { 9. Implementing laws } \\
\text { (錯法) }\end{array}$ & $\begin{array}{l}\text { post-306 } \\
\text { B.C.E. }\end{array}$ & $\begin{array}{l}\text { Mentions Qin strongman Wu Huo } \\
\text { (d. } 306 \text { B.C.E.) }\end{array}$ \\
\hline $\begin{array}{l}\text { 10. Methods of war (戰 } \\
\text { 法) }\end{array}$ & $\begin{array}{l}360-300 \\
\text { B.C.E. }\end{array}$ & $\begin{array}{l}\text { Unawareness of cavalry suggests pre- } \\
300 \text { date }\end{array}$ \\
\hline $\begin{array}{l}\text { 11. Establishing the } \\
\text { roots (立 本) }\end{array}$ & $\begin{array}{l}360-300 \\
\text { B.C.E. }\end{array}$ & $\begin{array}{l}\text { Unawareness of cavalry suggests pre- } \\
300 \text { date }\end{array}$ \\
\hline $\begin{array}{l}\text { 12. Military defense (兵 } \\
\text { 守) }\end{array}$ & $\begin{array}{l}\text { pre-36o } \\
\text { B.C.E. }\end{array}$ & $\begin{array}{l}\text { Geographical and military } \\
\text { information relates it to the state of } \\
\text { Wei, prior to Shang Yang's arrival in } \\
\text { Qin }\end{array}$ \\
\hline $\begin{array}{l}\text { 13. Making orders strict } \\
\text { (靳令) }\end{array}$ & $?$ & $\begin{array}{l}\text { A composite chapter, related to or } \\
\text { derivative of chapter } 4\end{array}$ \\
\hline $\begin{array}{l}\text { 14. Cultivation of } \\
\text { authority (修權) }\end{array}$ & $?$ & $\begin{array}{l}\text { The first to discuss administrative } \\
\text { affairs; sounds more } \\
\text { accommodating toward ideological } \\
\text { opponents than earlier chapters }\end{array}$ \\
\hline
\end{tabular}


Table 1. Continued

\begin{tabular}{|c|c|c|}
\hline Chapter & Dating & Comments \\
\hline $\begin{array}{l}\text { 15. Attracting the } \\
\text { people (徠民) }\end{array}$ & $\begin{array}{l}255^{-240} \\
\text { B.C.E. }\end{array}$ & $\begin{array}{l}\text { Dating is based on the chapter's } \\
\text { historical data }\end{array}$ \\
\hline $\begin{array}{l}\text { 17. Rewards and } \\
\text { punishments (賞刑) }\end{array}$ & $\begin{array}{l}\text { post-325 } \\
\text { B.C.E. }\end{array}$ & $\begin{array}{l}\text { Uses the term wang as the ruler's } \\
\text { appellation }\end{array}$ \\
\hline $\begin{array}{l}\text { 18. Charting the policies } \\
\text { (畫策) }\end{array}$ & $?$ & $\begin{array}{l}\text { A composite chapter, dating } \\
\text { impossible }\end{array}$ \\
\hline $\begin{array}{l}\text { 19. Within the borders } \\
\text { (境 內) }\end{array}$ & $\begin{array}{l}350-300 \\
\text { B.C.E.? }\end{array}$ & $\begin{array}{l}\text { Reflects early stages of Qin's "ranks of } \\
\text { merit" system, but possibly penned } \\
\text { after } 325 \text { B.C.E. }\end{array}$ \\
\hline $\begin{array}{l}\text { 20. Weakening the } \\
\text { people (弱民) }\end{array}$ & $\begin{array}{l}350-300 \\
\text { B.C.E.? }\end{array}$ & $\begin{array}{l}\text { Exegesis of chapter } 4 \text {; section } 20.11 \text { is } \\
\text { unrelated to the rest of the chapter } \\
\text { and is much later }\end{array}$ \\
\hline $\begin{array}{l}\text { 22. External and } \\
\text { internal (外内) }\end{array}$ & $?$ & No clear indicators \\
\hline $\begin{array}{l}\text { 23. Ruler and ministers } \\
\text { (君臣) }\end{array}$ & $?$ & No clear indicators \\
\hline $\begin{array}{l}\text { 24. Interdicting and } \\
\text { encouraging (禁使) }\end{array}$ & $?$ & $\begin{array}{l}\text { Sophisticated style and peculiar } \\
\text { content (focus on administration) } \\
\text { may suggest a late date of } \\
\text { composition, but currently this is } \\
\text { unverifiable }\end{array}$ \\
\hline $\begin{array}{l}\text { 25. Attention to law (慎 } \\
\text { 法) }\end{array}$ & $?$ & $\begin{array}{l}\text { Sophisticated administrative thought } \\
\text { may indicate relative lateness, but } \\
\text { currently this is unverifiable }\end{array}$ \\
\hline $\begin{array}{l}\text { 26. Fixing divisions (定 } \\
\text { 分) }\end{array}$ & $\begin{array}{l}\text { C. } 230 \\
\text { B.C.E.? }\end{array}$ & $\begin{array}{l}\text { Reflects administrative realities from } \\
\text { the eve of the imperial unification of } \\
221 \text { B.C.E. }\end{array}$ \\
\hline
\end{tabular}

* Note: Chapters 16 and 21 are lost.

再論先秦文獻的年代問題: 以《商君書》為例

\section{尤銳 \\ 提要}

本文討論《商君書》各篇的寫作年代。儘管《商君書》是戰國時代政治 思想最重要作品之一，但它長期被西方主流學術界所忽略。其被忽略的 主要原因是該書的寫作年代不清晰。我在文章中討論了其他學者在判斷 《商君書》各篇的寫作年代時所採用的標準及該標準的得失。文章所採 
用的極具透明性的研究方法，不僅有助於提高我們對《商君書》的本質 和寫作過程的了解，而且也初步嘗試了提出適用于其他先秦文獻寫作年 代研究的共同標準。作者希望这种標準能被廣泛接受以改善我們對諸子 百家文獻年代問題的研究方法。

Keywords: authenticity, Book of Lord Shang, dating, Shang Yang, Warring States

真䳕，《商君書》，寫作年代，商鞅，戰國時代，諸子百家 